Preprint of: Esher, Louise. 2016. Morphomic distribution of augments in varieties of Occitan. Revue Romane 51(2). 271-306.

\title{
Morphomic distribution of augments in varieties of Occitan ${ }^{1}$
}

Louise Esher

St John's College, University of Oxford

\begin{abstract}
This study examines the distribution and function of 'augments' within modern Occitan verb paradigms. Most augments in Occitan are reflexes of the Latin ingressive infix -(I/E) $)$ SC-, as in other Romance languages; but Occitan has also developed novel inflectional formatives which display similar behaviour. Like the reflexes of -(I/E)SC-, these formatives serve as inflectional class markers, and their paradigmatic distribution conforms to existing morphomic templates. The study provides an overview of the diverse paradigmatic distributions of augments encountered in Occitan; proposes an account of the origin of the novel formatives; and discusses the apparent correlation between the spread of augments and the neutralisation of conjugational class distinctions in inflectional desinences.
\end{abstract}

\section{Keywords}

Occitan; verb morphology; autonomous morphology; Romance linguistics; stem allomorphy; inflectional classes

\footnotetext{
${ }^{1}$ I am grateful to my colleagues Xavier Bach, Steven Kaye and Martin Maiden for much constructive discussion of the issues and data presented here, and to the two anonymous reviewers of this article for their comments and suggestions. None of the foregoing should be held responsible for any remaining errors.
} 
Preprint of: Esher, Louise. 2016. Morphomic distribution of augments in varieties of Occitan. Revue Romane 51(2). 271-306.

\section{Introduction}

This article investigates the distribution of so-called 'augments' within verb paradigms and inflectional classes in varieties of Occitan (Gallo-Romance), and the insights which their behaviour affords into two types of abstract morphological structure or 'morphomes' (Aronoff 1994): 'rhizomorphomes' and 'metamorphomes' in the typology of Round (2015).

'Rhizomorphomes' or 'inflectional classes', such as the different conjugations in Romance languages, divide the lexicon into groups of items with similar paradigms. 'Metamorphomes' or 'systematic paradigmatic distributions', such as the Romance N-pattern and U-pattern identified by Maiden (2009b, $2011 \mathrm{~b}$; see also §2.1), divide the inflectional paradigm into groups of cells with similar exponence (Round 2015: 29). Neither metamorphomes nor rhizomorphomes have an expressive function, but this does not mean that they have no function at all. On the contrary, both types of morphome provide a means of organising arbitrary allomorphy in a predictable way, and thus constitute a strategy for resolving the 'Paradigm Cell Filling Problem' identified by Ackerman et al. (2009: 54): if inflectional alternations, whatever their content, consistently follow a given template of paradigmatic distribution, speakers can draw more reliable inferences about the forms which realise different cells of the paradigm.

The data presented in this study provide evidence for the importance of established metamorphomes and rhizomorphomes as templates for the distribution of morphological formatives: in this case, 'augments' occurring in varieties of Occitan. The term 'augment' is used by Maiden (2004) to refer to inflectional formatives occurring between the lexical root and the inflectional desinences in Romance verb forms (e.g. -isc- in Italian finisco 'I finish'). Augments in Italo-, Ibero- and Rhaeto-Romance, particularly those continuing the Latin ingressive infix -SC-, have received extensive attention from morphologists, since their paradigmatic distributions systematically correspond to established metamorphomes (see e.g. Maiden 2004², Meul 2010, Meul 2013 for discussion) and since they also have a role as markers of inflectional class (Meul 2013). Under Matthews' (2014) definition of exponence as 'any relation between a linguistic unit, structure, etc. and its realization in speech', and 'any relation of realization by which this is mediated', augments can thus be classed among the exponents of morphomic structures. In a wordform realising a paradigm cell of a lexeme, the presence of an augment conveys information both about the rhizomorphome to which the lexeme belongs, and about the metamorphome to which the paradigm cell belongs.

The present study complements existing comparative work by examining the variety of augment distributions occurring in Occitan, and the diachronic developments which have produced these distributions. In varieties of Occitan, as in other Romance languages, augments continuing -SC- serve as exponents of both metamorphomes and rhizomorphomes. However, many Occitan varieties have additionally developed novel 'velar augments' (originating in the continuants of Latin perfectum ${ }^{3}$ forms), which will be shown to have a similar function. The presence of multiple augments permits investigation

\footnotetext{
${ }^{2}$ The work by Maiden cited in this article is largely concerned with the patterns which Round (2015) labels metamorphomes, though Maiden himself does not use this term, and refers to the patterns as 'morphomes'. For consistency, I will use the term 'metamorphome' throughout.

${ }^{3}$ Latin verbs have three stems: the 'present' or infectum stem, the 'perfect' or perfectum stem and the so-called 'third stem' (Aronoff 1994: 54-58). The infectum and perfectum stems are partially correlated with imperfective and perfective aspect respectively (see also Maiden 2013: 495).
} 
Preprint of: Esher, Louise. 2016. Morphomic distribution of augments in varieties of Occitan. Revue Romane 51(2). 271-306.

of the interaction between augments, in addition to the interaction between augments and other inflectional class markers, principally theme vowels.

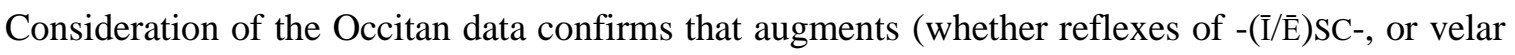
augments) are systematically distributed according to existing metamorphomic patterns. This finding recalls the behaviour of augments in other Romance languages, as well as that of novel alternations arising through defectiveness, suppletion, heteroclisis and analogy (see e.g. Maiden 2009b, 2011b): the developments observed in Occitan, as elsewhere in Romance, all illustrate the same underlying principle of organising arbitrary allomorphy according to established morphological templates.

This consistency can be explained as an adaptive strategy to increase the predictability, and hence the learnability, of inflectional paradigms. The data further indicate that the analogical extension of rhizomorphome exponents is constrained by metamorphomes, and vice versa: exponents of rhizomorphomes spread through individual paradigms one metamorphome at a time, and exponents of metamorphomes spread through the lexicon one inflectional class at a time. That the relationship between rhizomorphomes and metamorphomes is orthogonal, not hierarchical, is corroborated by the observation that marking of rhizomorphomes does not take precedence over marking of metamorphomes, while a given metamorphomic pattern can have a visible exponent in any or all conjugational classes.

The article is structured as follows. In $\S 2$, I outline the historical source and development of the SC- and velar augments in Romance, prior to describing, in $\S 3$, the diverse distributions of augments found in varieties of Occitan. The focus is on second-conjugation verbs (i.e. verbs with theme vowel/i/, continuing the Latin fourth conjugation ${ }^{4}$ ), in which augments are systematically present in all varieties; however, some varieties have only -SC- augments, while others also present a variant of the velar augment. The origin of this latter variant is discussed in $\S 4$, where I present arguments for distinguishing it from -SC- augments despite its often similar shape. Finally, in $\$ 5$, I illustrate the correlation between the extent of augments within a paradigm and the extent to which conjugation class distinctions have been neutralised, drawing conclusions on the relationship between metamorphome exponence and rhizomorphome exponence.

\section{Origin and development of augments in Romance}

Maiden (2004) and Meul (2013) discuss two major categories of augment in the Romance languages: reflexes of the Latin ingressive infix -SC-, and reflexes of a Latin derivational affix -ID(I)-. Both types are present in Occitan, though only the first will be of interest to the present study. ${ }^{5}$ A third type of augment, confined to Occitan and Catalan, involves a velar element originating in the perfectum stem of a small number of verbs. In this section, I outline the development of these augments in Romance, prior to more extensive discussion of the Occitan data.

\footnotetext{
${ }^{4}$ The i-conjugation is labelled II by Alibèrt (1976) and most grammars thereafter, as is the practice for French; note, however, that Ronjat (1937) and Wheeler (1988) label the i-conjugation III, as is the practice for Catalan and Italian. ${ }^{5}$ In Occitan, whereas the reflexes of -ĒSC- and -īSC- participate in a systematic and productive inflectional pattern applying to almost all second-conjugation lexemes, the reflexes of -ID(I)- occur throughout the paradigm of an arbitrary, lexically specified set of first-conjugation verbs. The fact that they are restricted to (a subset of) the first conjugation in Occitan generally precludes their interaction with other augments and thus limits the interest of these formatives to the present study.
} 
Preprint of: Esher, Louise. 2016. Morphomic distribution of augments in varieties of Occitan. Revue Romane 51(2). 271-306.

\section{$2.1 \quad$ Reflexes of -İSC-/-ESC-}

In early Latin, the distribution of the infix -SC- was semantically motivated, as the infix conveyed ingressive meaning (Maiden 2004: 8); within the paradigm, this infix was restricted to infectum forms (Da Tos 2013: 50-51). In modern Romance varieties, however, the continuants of second-conjugation -ËSC- and fourthconjugation -īSC- are either meaningless or cannot systematically be associated with a general meaning (Maiden 2004: 9-13). With the dissociation of augments from semantic content, the originally restricted range of lexemes presenting an augment has been significantly extended, and the paradigmatic distribution of augments has been conventionalised such that they occur predictably in a consistent set of cells.

In some varieties, such as Sardinian, Castilian and Portuguese, augments typically occur throughout the paradigm (Maiden 2011b: 251), while in others they are restricted to a subset of paradigm cells, as in Italian (Maiden 2004, Da Tos 2013), Catalan (Fabra 1966: 42-43) and Valencian (Sanchis Guarner 1950: 155-156). In most cases, a given variety will retain and generalise either reflexes of -ĒSC- or of -īSC-, but not of both: '[a]s a general rule, repeatedly confirmed by individual dialect studies, if a dialect has -isk- it does not have -esk-, and vice versa' (Maiden 2004: 19). Standard Italian, for instance, continues -ĩSC- (Table 1), whereas standard Catalan continues -ĒSC- (Table 2). In both these varieties, the distribution of augments corresponds to the metamorphome labelled 'N-pattern' by Maiden (e.g. 2005, 2009a), which consists of the cells \{1SG.PRS.IND, 2SG.PRS.IND, 3SG.PRS.IND, 3PL.PRS.IND, 1SG.PRS.SBJV, 2SG.PRS.SBJV, 3SG.PRS.SBJV, 3PL.PRS.SBJV, 2SG.IMP \}: all and only N-pattern cells present an augment.

\begin{tabular}{llllllll}
\hline & PRS.IND & IPFV.PST.IND & PRS.SBJV & PFV.PST.IND & IPFV.SBJV & FUT & COND \\
\hline 1SG & finisco & finivo & finisca & finii & finissi & finirò & finirei \\
2SG & finisci & finivi & finisca & finisti & finissi & finirai & finiresti \\
3SG & finisce & finiva & finisca & finì & finisse & finirà & finirebbe \\
1PL & finiamo & finivamo & finiamo & finimmo & finissemo & finiremo & finiremmo \\
2PL & finiate & finivate & finiate & finiste & finiste & finirete & finireste \\
3PL & finiscono & finivano & finiscano & finirono & finissero & finiranno & finirebbero \\
\hline
\end{tabular}

Table 1. Modern standard Italian finire 'finish'. Forms with an augment are shaded.

\begin{tabular}{llllllll}
\hline & PRS.IND & IPFV.PST.IND & PRS.SBJV & PFV.PST.IND & IPFV.SBJV & FUT & COND \\
\hline 1SG & fineixo & finia & fineixi & finí & finís & finiré & finiria \\
2SG & fineixes & finies & fineixis & finires & finissis & finiràs & finiries \\
3SG & fineix & finia & fineixi & finí & finís & finirà & finiria \\
1PL & finim & finíem & finim & finírem & finíssim & finirem & finiríem \\
2PL & finiu & finíeu & finiu & finíreu & finíssiu & finireu & finiríeu \\
3PL & fineixen & finien & fineixin & finiren & finissin & finiran & finirien \\
\hline
\end{tabular}

Table 2. Modern standard Catalan finir 'finish'. Forms with an augment are shaded. 
Preprint of: Esher, Louise. 2016. Morphomic distribution of augments in varieties of Occitan. Revue Romane 51(2). 271-306.

An individual variety may, however, present multiple reflexes of -īsC-, or of -ĒSC-, due to the context-sensitive development of / $\mathrm{k} /$. Standard Italian, for example, presents an alternation between /isk/ in contexts where $/ \mathrm{k} /$ preceded a non-front vowel and was conserved (1SG.PRS.IND, 3PL.PRS.IND, all PRS.SBJV cells), and /ifJ/ in contexts where $/ \mathrm{k} /$ preceded a front vowel and underwent palatalisation (2SG.PRS.IND, 3SG.PRS.IND). Although the phonological processes responsible for this alternation are now defunct, the alternation itself persists (mediaeval Italian and modern standard Italian both show the same distribution, see Maschi \& Vanelli 2010: 1462-1463).

Like the overall distribution of augment presence/absence within the paradigm, the distribution of the forms /isk/ and /i $\int \mathrm{J} /$ in modern Italian also corresponds to morphomic patterns of paradigmatic distribution which exist in other lexemes. ${ }^{6}$ The domain of the N-pattern overlaps with that of the 'U-pattern' (see e.g. Maiden 2009a), a metamorphome comprising 1SG.PRS.IND, 3PL.PRS.IND and all PRS.SBJV cells. The presence of augments is overall confined to the N-pattern; but within this set, the cells \{1SG.PRS.IND, 3PL.PRS.IND, 1SG.PRS.SBJV, 2SG.PRS.SBJV, 3SG.PRS.SBJV, 3PL.PRS.SBJV \}, which are also members of the Upattern, present the form /isk/, whereas the others present the form /iff/.

The alternation between /isk/ and /ifJ/ is one among many examples of U-pattern alternation resulting directly from regular sound change; the U-pattern arises precisely due to the palatalisation of velars before front vowels. The N-pattern distribution of augments, however, results from a purely morphological change, redistributing a meaningless inflectional formative according to an established morphomic template; although the N-pattern distribution is itself arbitrary, it is consistent and predictable for speakers.

In modern standard Catalan, by contrast, a single reflex, -eix- <-ĒSC- is present in all N-pattern cells. Comparison of modern standard Catalan with mediaeval Catalan shows that this distribution is a recent innovation, replacing the etymological pattern of alternation between -esc-and -eix- (Table 3); note however that the mediaeval pattern is continued in other modern Catalan varieties, such as that of Mallorca (Moll 1952: 243).

\begin{tabular}{lll}
\hline & PRS.IND & PRS.SBJV \\
\hline 1SG & partesc & partesca \\
2SG & parteixs & partesques \\
3SG & parteix & partesca \\
1PL & partim & partescam \\
2PL & partits & partescats \\
3PL & parteixen & partesquen \\
\hline
\end{tabular}

Table 3. Partial paradigm for mediaeval Catalan partir 'leave' (Moll 1952: 243-244). The alternation between $\langle\mathrm{sc}\rangle$ and $\langle\mathrm{squ}\rangle$ is purely orthographic; both sequences denote/sk/. Forms with an augment are shaded (in darker grey for the palatalised variant).

\footnotetext{
${ }^{6}$ See Maiden (2005, 2009a) for an overview of Romance morphomes and their source.
} 
Preprint of: Esher, Louise. 2016. Morphomic distribution of augments in varieties of Occitan. Revue Romane 51(2). 271-306.

In French, the augment has a wider distribution. In mediaeval French, a reflex of -İSC- occurred throughout the PRS.IND, PRS.SBJV, IPFV.PST.IND, IMP and PRS.PTCP (Pope 1934: 336, Buridant 2000: 245). Subsequently, second-conjugation lexemes are a major locus for the rise of a novel morphomic pattern (triggered by the deletion of final consonants, and largely obliterating the N-pattern), in which the plural PRS.IND forms share a stem with all IPFV.PST.IND forms, and often some or all PRS.SBJV forms, but not singular PRS.IND forms. The resulting augment-distribution is shown in Table 4. ${ }^{7}$ Diachronically, as observed by Meul (2013: 100), the contrast between il finit (<*finiscit) and il sent (< SENTIT) is evidence for the presence of the augment in the singular forms of the PRS.IND. Synchronically, however, there is no obvious reason for speakers of French to associate the /i/ of PRS.IND forms such as finit with the augment /is/ rather than with the second-conjugation theme vowel /i/. (Note that in French, /i/ and /is/ are in complementary distribution within the paradigm, Meul 2013: 105).

\begin{tabular}{|c|c|c|c|c|c|}
\hline & PRS.IND & IPFV.PST.IND & PRS.SBJV & FUT & COND \\
\hline $1 \mathrm{SG}$ & fini & finise & finis & finise & finise \\
\hline $2 \mathrm{SG}$ & fini & finise & finis & finisa & finise \\
\hline $3 \mathrm{SG}$ & fini & finise & finis & finisa & finise \\
\hline $1 \mathrm{PL}$ & finisว̃ & finisjõ & finisjõ & finisว̃ & finisjõ \\
\hline 2PL & finise & finisje & finisje & finise & finisje \\
\hline 3PL & finis & finise & finis & finiьว̃ & finise \\
\hline
\end{tabular}

Table 4. Modern standard French finir 'finish'. Forms with the augment /is/ are shaded.

Overall, the paradigmatic distribution of augments continuing -ĒSC- and -İSC- differs considerably between Romance varieties, but in each variety the distribution of augments corresponds to established metamorphomic templates in that variety. Where metamorphomic templates conflict with one another, augments may be analogically redistributed. The reflexes of -ËSC- and -īSC- can develop their own internal allomorphy through regular sound change, and in some cases the novel allomorphs are subsequently redistributed according to morphomic templates: in standard Italian, the 1PL.PRS.SBJV and 2PL.PRS.SBJV lose their augment but the contrast between /isk/ and /ifJ/ is retained, while in standard Catalan, the form eix- is generalised across all N-pattern cells, eliminating -esc-. Similar processes and distributions will be found in Occitan ( $\$ 3$ below), where some varieties continue -ESC-, some -īsC-, and still others both.

\footnotetext{
${ }^{7}$ The simple past and imperfect subjunctive are omitted, as these forms are no longer spontaneously acquired by native speakers.
} 
Preprint of: Esher, Louise. 2016. Morphomic distribution of augments in varieties of Occitan. Revue Romane 51(2). 271-306.

\subsection{The velar element}

While the augments investigated by Maiden (2004) and Meul (2013) can be traced back to infixes in Latin, this is not the case for all augments found in Occitan. In this section, I outline the source of a further element which can be analysed as an augment, and which ultimately enters into interaction with -ËSC- and -İSC- augments: a velar formative /sk/ or /g/, originating in Latin perfectum forms.

The reflexes of Latin perfectum forms together constitute a morphome labelled 'PYTA' ${ }^{8}$ by Maiden (2001). In the Occitan varieties discussed here, PYTA consists of the simple past and imperfect subjunctive; a velar formative is present throughout PYTA in many third-conjugation verbs, but is also commonly generalised to second-conjugation verbs. The analogical spread of the velar formative can also affect the present subjunctive, in which -ĒSC- and -ĪSC- augments could already occur.

Velar formatives are also found in Catalan, where the L-pattern ${ }^{9}$ and PYTA have merged (Wheeler 2011). For the modern standard variety of Barcelona, Wheeler (2011: 185) identifies over forty lexemes with /g/ in their PYTA/L-pattern root, and a further handful with the sequence /sk/ (unlike in Occitan, the i-conjugation is not affected). The distribution found is illustrated in Table 3 for prendre 'take' in modern standard Catalan: all PYTA and L-pattern forms share a distinctive root ending in a velar stop. The contrast between $/ \mathrm{k} /$ in the 1SG.PRS.IND and $/ \mathrm{g} /$ in all other forms is explained by the presence of a general rule of final obstruent devoicing in Catalan: 1SG.PRS.IND is the only form in which the root-final velar is also wordfinal.

\begin{tabular}{llllllll}
\hline & PRS.IND & IPFV.PST.IND & PRS.SBJV & PFV.PST.IND & IPFV.SBJV & FUT & COND \\
\hline 1SG & prenc & prenia & prengui & prenguí & prengués & prendré & prendria \\
2SG & prens & prenies & prenguis & prengueres & prenguessis & prendràs & prendries \\
3SG & pren & prenia & prengui & prengué & prengués & prendrà & prendria \\
1PL & prenem & preníem & prenguem & prenguérem & prenguéssim & prendrem & prendríem \\
2PL & preneu & preníeu & prengueu & prenguéreu & prenguéssiu & prendreu & prendríeu \\
3PL & prenen & prenien & prenguin & prengueren & prenguessin & prendran & prendrien \\
\hline
\end{tabular}

Table 5. Modern standard Catalan prendre 'take' (Fabra 1966: 57). Forms with a velar root are shaded.

The origin of the velar is traced for both Occitan and Catalan by Wheeler (2011). Velar consonants in the L-pattern are etymological in a number of third-conjugation lexemes, arising variously from intervocalic -C- (DICO > dic 'say.1SG.PRS.IND') and postconsonantal -G- (STRINGO > estrenc 'squeeze.1SG.PRS.IND') as well as originally ingressive -SC- (Wheeler 2011: 189). They are spread by analogy to other lexemes, chiefly those which already had a velar element in PYTA (Wheeler 2011: 190).

\footnotetext{
${ }^{8}$ The arbitrary label 'PYTA' is derived from the term perfecto y tiempos afines used in traditional Spanish grammar to designate these forms. It is valuable to give metamorphomes arbitrary labels so that the abstract groupings of paradigm cells can be discussed independently of the phonological, syntactic and semantic content associated with them.

${ }^{9}$ The L-pattern consists of all PRS.SBJV cells together with the 1SG.PRS.IND cell.
} 
Preprint of: Esher, Louise. 2016. Morphomic distribution of augments in varieties of Occitan. Revue Romane 51(2). 271-306.

Few lexemes appear to have had an etymological velar in PYTA; Wheeler (2011: 195), following Ronjat (1937: 178), argues that this element originated in forms ${ }^{10}$ such as plac 'please.3SG.PST.PFV.IND' < PLACUIT and noc 'harm.3SG.PST.PFV.IND' < NOCUIT by regular sound change, subsequently spreading into rhizotonic (root-stressed) preterites such as $a c$ 'have.3SG.PST.PFV.IND', volc 'want.3SG.PST.PFV.IND' and poc 'be_able.3SG.PST.PFV.IND' (Maiden 1996: 187), thence into all PYTA forms of these lexemes, and then into many further third-conjugation lexemes. In Catalan, the variant/sk/ appears to have spread in the other direction, from the L-pattern into PYTA (Wheeler 2011). ${ }^{11}$ Subsequently, 'innovations [...] to unify Lpattern and PyTA [sic] stems have been carried out using non-velar stem variants, a process which confirms that the morphome is more abstract than its typical expression' (Wheeler 2011: 209).

In most varieties of Occitan, the L-pattern has been reduced ${ }^{12}$ to a morphome coextensive with the PRS.SBJV (Maiden forthcoming 2016). Identity between the PRS.SBJV ${ }^{13}$ root and the PYTA root is not exceptionless, but is a common pattern. Third-conjugation verbs with a distinctive PYTA root may present either $/ \mathrm{sk} /$ or $/ \mathrm{g} /$; which variant is found is subject to lexical and regional variation.

Among the most interesting aspects of the Occitan data is that equivalent velar elements $/ \mathrm{g} /$ and /sk/ are also introduced analogically into the PYTA forms of second-conjugation verbs, though never in isolation: they always occur as part of a string -ig- or -isc-. These strings, resembling augments, occur in complementary distribution with the reflex(es) of -ËSC- and/or -īSC-, and with the second-conjugation theme vowel /i/; they are discussed in more detail in $\S 4.1$ and $\S 4.2$ below.

\section{Patterns of augment-distribution in Occitan}

In Occitan, the majority, regular and productive pattern for second-conjugation verbs (i.e. the reflexes of Latin fourth-conjugation verbs) has, since at least mediaeval times, included one or more augments in a subset of the paradigm. There is, however, extensive regional variation in the paradigmatic distribution of augments, the range of augments present and their phonological form. This very diversity, an illustrative sample of which is provided here, highlights an important constant: all the distributions correspond to existing metamorphomic templates for allomorphy. Indeed, the variation observed indicates that it is indeed

\footnotetext{
${ }^{10}$ In the absence of early Catalan attestations, Wheeler cites mediaeval Occitan forms.

${ }^{11}$ In Catalan, /sk/ may occasionally result from metathesis in perfective stems in -X-: VIXIT TRAXIT SCRIPSIT FUGIT > visc trasc escrisc fusc (Wheeler 2011: 199). Metathesis is not, however, a viable explanation for /sk/ forms in Occitan, where regular sound change would predict that e.g. *viscit produces not *visc but *vis.

${ }^{12}$ The principal cause is the deletion of final unstressed vowels other than /a/ in early Gallo-Romance. Following this change, stem-final consonants in the 1SG.PRS.IND become word-final, whereas stem-final consonants throughout the PRS.SBJV remain word-medial. Due to context-sensitive sound changes acting differentially on word-final and wordmedial segments, the stem of the 1SG.PRS.IND is differentiated from that of the PRS.SBJV, often coming to resemble that of the 2SG.PRS.IND and 3SG.PRS.IND instead. There remains scant evidence from which speakers could deduce a systematic, recurrent L-pattern; whereas the pattern of a distinctive stem for the PRS.SBJV is a common one. The person marker $-i$ found in most modern Occitan 1SG.PRS.IND forms is of analogical origin (Ronjat 1937: 154). See also Nevins et al. (2015) for the role of lexical type frequency in the maintenance, loss and modification of metamorphomic patterns.

${ }^{13}$ And also the gerund, where it exists, see Maiden (1996: 184-187).
} 
Preprint of: Esher, Louise. 2016. Morphomic distribution of augments in varieties of Occitan. Revue Romane 51(2). 271-306.

this abstract organisational principle which matters to speakers, rather than the association of a given augment with a given cell or expressive function.

The majority of varieties support Maiden's generalisation (2004: 9-13) that any individual variety will continue either -ĪSC- or -ĒSC-. In general, -ĒSC- is continued west of the river Garonne, and -īSCelsewhere (see Bec 1968: 220-223 for a detailed description) although occasional varieties on the border between the two areas, notably in Ariège, present continuants of both (Ravier 1970: 21, Maiden 2004: 20). ${ }^{14}$ The regular outcome of İSC preceding a front vowel is -iss- /is/ (or /if/ in western and northern varieties), and preceding a back vowel -isc- /isk/; the regular outcome of ĒSC preceding a front vowel is -éish- leij/ (also -éiss- /eis/ or -ésh- /e J/), and preceding a back vowel is -esc- /esk/ (see Ravier 1970: 20).

In mediaeval Occitan, several distributions of augments are attested (Skårup 1997: 82-84). In the 1SG.PRS.IND, both -isc- (due to regular sound change) and -iss- (by analogy with other PRS.IND forms) are attested. ${ }^{15}$ In some texts, there is no augment in the 1PL.PRS.IND, 2PL.PRS.IND and IPFV.PST.IND. For the 1PL.PRS.SBJV and 2PL.PRS.SBJV, Skårup only finds examples with an augment; however, attestations of 1PL.PRS.SBJV and 2PL.PRS.SBJV are so rare overall that the absence of augmentless variants in texts cannot be taken as a reliable indication that augmentless 1PL.PRS.SBJV and 2PL.PRS.SBJV never occurred. The augment is never found in the INF, FUT and COND, or the continuants of perfectum forms (Skårup 1997: 82,84). Its absence from PYTA is not unexpected, since the infix -SC- was not found in the perfective predecessors of PYTA forms (see Meul 2013: 59-60, who makes the interesting point that the distribution of this infix in Latin mapped onto an existing opposition between infectum and perfectum stems; in effect, its distribution was already morphomic ${ }^{16}$ ). The INF, however, could present the infix -SC-, whether as part of a non-derived stem (as in POSCERE 'ask', MISCERE 'mix', Meul 2013: 53) or as part of a formative deriving inchoative verbs (as in FRIGESCERE 'become cold', ALBESCERE 'turn white', Meul 2013: 53-54).

In modern Occitan, there is extensive regional variation in the paradigmatic distribution of augments. A rare constant is that no variety has an augment in the INF or PST.PTCP. In some varieties, augments are confined to the N-pattern, but this pattern is rare; augments are generally found throughout the PRS.IND and IPFV.PST.IND (see e.g. Casagrande 2011). In many varieties, a formative resembling the augment occurs throughout PYTA forms; and in a small number, an augment is also found throughout the FUT and COND, which together constitute a metamorphome labelled 'Fuèc' ${ }^{17}$ by Esher (2012a, 2013).

Regional variation also affects the range of augments present. In some varieties of Provence and those around Nice (Martin \& Moulin 2007: 93-95, Toscano 1998: 102; Tables 7 and 8), all augmented

\footnotetext{
${ }^{14}$ Casagrande (2011: 104), on the contrary, claims that all modern augments are derived from -īsc-. However, his analysis overlooks the differential development of Latin I I and I in early Romance, citing PǏSCEM > peish 'fish' as evidence that -eish-is the expected reflex of -īsC- in Ariège. This false step forces him to invoke an alternative explanation for the presence of -iss-/-ish-alongside -eish-in these varieties; he suggests contact.

${ }^{15}$ This development is entirely concurrent with the loss of the L-pattern from most varieties of Occitan (for which see fn.9 above).

${ }^{16}$ Aronoff (1994: 25) treats all paradigmatic stem distributions as morphomic, from those which do correspond to a natural class, to those which are functionally arbitrary.

${ }^{17}$ Fuèc comprises the Romance synthetic future and synthetic conditional derived from Latin periphrases INF + 'have'. The label, literally meaning 'fire', is the regular reflex of FOCUS 'hearth' in eastern varieties of Occitan, and a near-acronym of the Occitan term futur e condicional 'future and conditional'. Evidence for the metamorphomic status of Fuèc is adduced by Esher (2012a, 2012b, 2013).
} 
Preprint of: Esher, Louise. 2016. Morphomic distribution of augments in varieties of Occitan. Revue Romane 51(2). 271-306.

forms present -iss-, but in the south-western Languedoc both -iss- and -isc-/-isqu- ${ }^{18}$ are found. Many varieties additionally present an augment -ig- or -isqu- in PYTA, which, though not dissimilar in appearance and distribution to the reflexes of -İSC- and -ĒSC-, is of separate origin, as will be discussed in $\S 4$. An impression of the diversity observed may be gained from the selection of second-conjugation paradigms presented in this section.

Table 6 shows a distribution common in varieties of Gascony, closely resembling what would be expected on etymological grounds. An augment - esc- <-ĒSC is found throughout the PRS.SBJV; this augment would also have been expected in the 1SG.PRS.IND, but has undergone analogical levelling, being replaced with -eish-<-ĒSC-. The form - eish- is confined to all singular PRS.IND cells, 3PL.PRS.IND and 2SG.IMP. The IPFV.SBJV, which continues the Latin PLPF.SBJV, displays a formative -iss- which is the regular reflex of the PLPF.SBJV marker -İSS- (e.g. FLORUISSET 'flower.3SG.PLPF.SBJV' > florisse 'flower.3SG.IPFV.SBJV').

\begin{tabular}{llllllll}
\hline & PRS.IND & IPFV.PST.IND & PRS.SBJV & PFV.PST.IND & IPFV.SBJV & FUT & COND \\
\hline 1SG & basteishi & bastivi & bastesqui & bastii & bastissi & bastirèi & bastirí \\
2SG & basteishes & bastivas & bastescas & bastís & bastisses & bastiràs & bastirés \\
3SG & basteish & bastiva & bastesca & bastí & bastisse & bastirà & bastiré \\
1PL & bastim & bastívam & bastescam & bastim & bastíssem & bastiram & bastirem \\
2PL & bastitz & bastívatz & bastescatz & bastitz & bastíssetz & bastiratz & bastiretz \\
3PL & basteishen & bastívan & bastescan & bastín & bastissen & bastiràn & bastirén \\
\hline
\end{tabular}

Table 6. bastir 'build', Béarn (Grosclaude \& Nariòo 1998: 46). Forms with an augment are shaded (-eishin light grey, -esc- in dark grey).

In most other varieties, such as the standard Provençal of Table 7, the augment found is a reflex of -İSC-. This augment is found throughout the reflexes of infectum forms, reflecting the distribution of -īSCin Latin, and also appears throughout PYTA. It is, however, absent from the FUT, COND, INF and PST.PTCP.

Comparison of Table 7 with Table 6 further shows a difference in the desinences of the PFV.PST.IND and IPFV.SBJV. Whereas the desinences -ii, -issi, etc. in Table 6 are etymological, the desinences -èri, -èssi in Table 7 are the result of an analogical process generalising a single set of PFV.PST.IND and IPFV.SBJV desinences (originally those of the third conjugation) to all conjugations (see Ronjat 1937: 177). In these forms, the element -iss- is therefore not etymological, and is most plausibly attributed to analogical spread of -iss- <-İSC- from the continuants infectum forms into PYTA (\$4.2).

\footnotetext{
${ }^{18}$ In standard Occitan orthography, $\langle\mathrm{c}>$ and $\langle\mathrm{qu}>$ are orthographic variants both denoting $/ \mathrm{k} /$; by convention, $\langle\mathrm{qu}>$ is used before $\langle\mathrm{i}\rangle$ and $\langle\mathrm{e}\rangle$, while $\langle\mathrm{c}\rangle$ is used before other vowels.
} 
Preprint of: Esher, Louise. 2016. Morphomic distribution of augments in varieties of Occitan. Revue Romane 51(2). 271-306.

\begin{tabular}{llllllll}
\hline & PRS.IND & IPFV.PST.IND & PRS.SBJV & PFV.PST.IND & IPFV.SBJV & FUT & COND \\
\hline 1SG & finissi & finissiáu & finissi & finissèri & finissèssi & finirai & finiriáu \\
2SG & finisses & finissiás & finisses & finissères & finissèsses & finiràs & finiriás \\
3SG & finisse & finissiá & finisse & finissèt & finissèsse & finirà & finiriá \\
1PL & finissèm & finissiam & finissem & finisseriam & finissessiam & finirem & finiriam \\
2PL & finissètz & finissiatz & finissetz & finisseriatz & finissessiatz & finiretz & finiriatz \\
3PL & finisson & finissián & finissen & finissèron & finissèsson & finiràn & finirián \\
\hline
\end{tabular}

Table 7. finir 'finish', Provence (Martin \& Moulin 2007: 93-95). Forms with an augment are shaded.

In varieties of Nice (Ronjat 1937: 229, Toscano 1996, 1998), exemplified in Table 8, and those of the surrounding area (Blinkenberg 1939, 1948), the augment is also a reflex of -İSC-. As in the Provençal data above, this augment is found throughout the reflexes of infectum forms, in the PRS.PTCP and in PYTA (where the desinences are again due to the same analogy). Additionally, the augment is found in Fuèc. ${ }^{19}$ The only forms into which -iss- does not spread are the PST.PTCP and INF. This is, to my knowledge, the most extensive paradigmatic distribution of an augment attested for Occitan, and is also found in some varieties of the Italian Alps (Bianco et al. 2008).

As in the Italo-Romance varieties discussed by Meul (2013: 112-117), the spread of the augment into Fuèc is accompanied by the spread of a non-second-conjugation theme vowel. In several Alpine varieties (Bianco et al. 2008, Jourdan 2009), as in Meul's data, this vowel is /a/, characteristic of the first conjugation. In Nissart, the theme vowel /e/, originally found in the first conjugation ${ }^{20}$ and a subset of thirdconjugation verbs, is generalised to Fuèc forms of all three conjugations, much as the PYTA desinences have been generalised across all three conjugations, potentially neutralising conjugational class distinctions. The apparent correlation between the spread of the augment (a distinguishing feature of second-conjugation verbs), and the loss of desinences unambiguously signalling conjugational class, will be discussed further in $\S 4.2$.

\begin{tabular}{llllllll}
\hline & PRS.IND & IPFV.PST.IND & PRS.SBJV & PFV.PST.IND & IPFV.SBJV & FUT & COND \\
\hline 1SG & finissi & finissii & finissi & finissèri & finissessi & finisserai & finisserii \\
$2 \mathrm{SG}$ & finisses & finissies & finisses & finissères & finissesses & finisseràs & finisseries \\
$3 \mathrm{SG}$ & finisse & finissia & finisse & finissèt & finissesse & finisserà & finisseria \\
$1 \mathrm{PL}$ & finissèm & finissiavam & finissèm & finisseriam & finissessiam & finisserèm & finisseriam \\
$2 \mathrm{PL}$ & finissètz & finissiavatz & finissètz & finisseriatz & finissessiatz & finisserètz & finisseriatz \\
3PL & finísson & finissíon & finísson & finissèron & finissésson & finisseràn & finisseríon \\
\hline
\end{tabular}

Table 8. finir 'finish', Nice. (Toscano 1998: 102). Forms with an augment are shaded.

\footnotetext{
${ }^{19}$ Forms such as finirai, partirai are given in descriptive grammars alongside finisserai, parterai (see e.g. Ronjat 1937: 228-229) but are described as confined to the literary language (Toscano 1998: 87).

${ }^{20}$ As in Italian (Maiden 1995: 44), intertonic /a/ before /r/ raises to /e/ in Nissart (Esher 2012a).
} 
Preprint of: Esher, Louise. 2016. Morphomic distribution of augments in varieties of Occitan. Revue Romane 51(2). 271-306.

Such extensive presence of a single augment throughout the paradigm is characteristic of the easternmost varieties of Occitan. In the Languedoc, it is more common to find a distribution resembling those in Table 9 (western Languedoc) and Table 10 (eastern Languedoc); the latter distribution is recommended by the normative grammar of Alibèrt (1976), and is also given by Martin \& Moulin (2007: 93-95) for Provence, as an alternative to the forms shown in Table 7. In both cases, -iss- <-îSC- is continued in the PRS.IND and IPFV.PST.IND. A second augment, -isc- or -ig-, is found throughout PYTA and the PRS.SBJV (which, as in Catalan, typically share a stem).

The form -ig- cannot be derived from either -īSC- or -ĒSC- through regular sound change. I will argue below ( $\$ 4$ that it arises by analogical spread of the velar element (\$2.2) present in the PYTA forms of many third-conjugation verbs. The lexical and paradigmatic distribution of the variant -isc- in PYTA indicates that it, too, is of analogical origin, despite its phonological identity with the augment $-i s c$ - < İSC found in the PRS.SBJV.

\begin{tabular}{llllllll}
\hline & PRS.IND & IPFV.PST.IND & PRS.SBJV & PFV.PST.IND & IPFV.SBJV & FUT & COND \\
\hline 1SG & bastissi & bastissiái & bastiscai & bastisquèi & bastisquèssi & bastirè & bastiriái \\
2SG & bastisses & bastissiás & bastiscas & bastisquèes & bastisquèssas & bastiràs & bastiriás \\
3SG & bastís & bastissiá & bastisca & bastisquèc & bastisquèssa & bastirà & bastiriá \\
1PL & bastissèm & bastissiám & bastiscam & bastisquèen & bastisquèssam & bastirem & bastiriám \\
2PL & bastissètz & bastissiátz & bastiscatz & bastisquèetz & bastisquèssatz & bastiretz & bastiriátz \\
& & & bastisquetz & & & & \\
3PL & bastissen & bastissián & bastiscan & bastisquèen & bastisquèssan & bastiràn & bastirián \\
\hline
\end{tabular}

Table 9. bastir 'build', Clermont-le-Fort (ALLOc 31.20). Forms with an augment are shaded (-iss- in dark grey, -isc-in lighter grey). The sequence <ri $>$ in the COND may be realised either $/ \mathrm{f} / \mathrm{or} / \mathrm{j} /$; the PFV.PST.IND forms probably derive from bastisquèvi, etc., via deletion of intervocalic / $\beta /$ (see Ronjat 1937: 193, and compare IPFV.PST.IND /kan'tao/vs. /kan'taßo/ in most other varieties).

\begin{tabular}{llllllll}
\hline & PRS.IND & IPFV.PST.IND & PRS.SBJV & PFV.PST.IND & IPFV.SBJV & FUT & COND \\
\hline 1SG & bastisse & bastissiá & bastigue & bastiguère & bastiguèsse & bastirai & bastiriá \\
2SG & bastisses & bastissiás & bastigues & bastiguères & bastiguèsses & bastiràs & bastiriás \\
3SG & bastís & bastissiá & bastigue & bastiguèt & bastiguèsse & bastirá & bastiriá \\
1PL & bastissèm & bastissiam & bastiguem & bastiguèren & bastiguèssem & bastirem & bastiriám \\
2PL & bastissètz & bastissiatz & bastiguetz & bastiguèretz & bastiguèssetz & bastiretz & bastiriátz \\
3PL & bastisson & bastissiáu & bastigon & bastiguèron & bastiguèsson & bastiráu & bastiriáu \\
\hline
\end{tabular}

Table 10. bastir 'build', Paulhan (ALLOr 34.07E). Forms with an augment are shaded (-iss- in dark grey, -ig- in lighter grey). <r> in the PFV.PST.IND, FUT and COND is purely orthographic. 
Preprint of: Esher, Louise. 2016. Morphomic distribution of augments in varieties of Occitan. Revue Romane 51(2). 271-306.

The distribution shown in Tables 9 and 10 is also common in the central and northern Languedoc (see ALLOc, ${ }^{21}$ ALLOr, Lieutard 2004), though with a different formative in PYTA and the PRS.SBJV (Table 11). Historically, these varieties presented the augment -ig- in the PRS.SBJV, PFV.PST.IND and IPFV.SBJV, but they have since undergone a sound change such that intervocalic $/ \mathrm{g} /$ is lenited to $[\mathrm{\gamma}]$, and subsequently deleted. An interesting consequence of this development is that the PYTA-augment, now realised as /i/, becomes syncretic with the second-conjugation theme vowel /i/ found in Fuèc, the INF and the PST.PTCP.

\begin{tabular}{llllllll}
\hline & PRS.IND & IPFV.PST.IND & PRS.SBJV & PFV.PST.IND & IPFV.SBJV & FUT & COND \\
\hline 1SG & bastissi & bastissiá & bastía & bastièri & bastièssi & bastirai & bastiriá \\
2SG & bastisses & bastissiás & bastías & bastièras & bastièssas & bastiràs & bastiriás \\
3SG & bastís & bastissiá & bastía & bastièt & bastièssa & bastirà & bastiriá \\
1PL & bastissèm & bastissiam & bastiem & bastièren & bastièssem & bastirem & bastiriam \\
2PL & bastissètz & bastissiatz & bastietz & bastières & bastièssetz & bastiretz & bastiriatz \\
3PL & bastisson & bastissiáu & bastíon & bastièron & bastièsson & bastiráu & bastiriáu \\
\hline
\end{tabular}

Table 11. bastir 'build', Pampelonne (ALLOC 81.10). Forms with the augment -iss- are shaded in dark grey, forms with the element $-i-<-i g$ - in lighter grey).

The most complex systems are found in the Pyrenees, around the source of the Garonne and in the valley below. Varieties such as that of the Val d'Aran (Table 12) ${ }^{22}$ combine N- and L-pattern distributions of -isc- and -iss- (as in Italian), with a unique distribution of the formative -ig-, found in the 1PL.PRS.SBJV, 2PL.PRS.SBJV, PFV.PST.IND and IPFV.SBJV. ${ }^{23}$ As in the Béarnais example shown in Table 6, no augment is found in the 1PL.PRS.IND, 2PL.PRS.IND or IPFV.PST.IND; nor is there any augment in the PFV.PST.IND, FUT or

${ }^{21}$ Each $A L L O C$ and ALLOr survey point is uniquely identified by a code of the form 12.34, the first two digits of which correspond to the number of the département in which the point is located, the second two being an arbitrary code for the survey point: Clermont-le-Fort (ALLOc 31.20) is point no. 20 in the département 31 (Haute-Garonne).

${ }^{22}$ Ademá Mora (1966) claims only serví, etc. in the PFV.PST.IND but only serviguessa, etc. in the IPFV.SBJV. If confirmed, this distribution would be significant as a rare case of asymmetry between members of PYTA (see Maiden 2011a: 183 for discussion of possible examples elsewhere in Romance, also Wheeler 2011: 203-204). However, both Carrera (2007) and Coromines (1991) give only symmetrical PYTA forms for this area. From Winkelmann (1989) it is clear that the distinction between PFV.PST.IND serví, etc. and serviguí, etc. is a stable case of dialectal variation; Winkelmann does not mention the IPFV.SBJV, but the data provided by Carrera indicate that the distinction between servissa, etc. and serviguessa, etc. is likewise dialectal. Thus the paradigm given by Ademá Mora most plausibly results from incomplete description.

${ }^{23}$ A similar template, in which 1PL.PRS.SBJV, 2PL.PRS.SBJV, PFV.PST.IND and IPFV.SBJV cells uniquely share a stem, is attested for some lexemes in the Asturian variety of the Alto Aller (Rodríguez Castellano 1952: 148-153). Maiden (2012: 39) attributes this pattern to speakers evicting the original PRS.SBJV root from the 1PL.PRS.SBJV and 2PL.PRS.SBJV (due to clash with the N-pattern) and seeking a replacement for it in 'the only other synthetic verb form which also expresses subjunctive', i.e. the IPFV.SBJV, which shares the root of the PFV.PST.IND. In the Val d'Aran, there is likewise clash of the N-pattern and L-pattern, resulting in eviction of the original PRS.SBJV root from the 1PL.PRS.SBJV and 2PL.PRS.SBJV. However, the selection of the -ig- form for 1PL.PRS.SBJV and 2PL.PRS.SBJV is more likely to be motivated by the general tendency for the PRS.SBJV, PFV.PST.IND and IPFV.SBJV cells to share a root, rather than any consideration of functional content. 
Preprint of: Esher, Louise. 2016. Morphomic distribution of augments in varieties of Occitan. Revue Romane 51(2). 271-306.

COND. Once again, the augmentless forms retain desinences which unambiguously identify the conjugational class of the lexeme.

\begin{tabular}{llllllll}
\hline & PRS.IND & IPFV.PST.IND & PRS.SBJV & PFV.PST.IND & IPFV.SBJV & FUT & COND \\
\hline 1SG & servisqui & servia & servisca & serviguí & serviguessa & servirè & serviria \\
2SG & servisses & servies & servisques & serviguéres & serviguesses & serviràs & serviries \\
3SG & servís & servie & servisque & serviguec & serviguesse & servirà & servirie \\
1PL & servim & servíem & servigam & serviguérem & serviguéssem & serviram & serviríem \\
2PL & servitz & servíetz & servigatz & serviguéretz & serviguéssetz & serviratz & serviríetz \\
3PL & servissen & servien & servisquen & serviguéren & serviguessen & serviràn & servirien \\
\hline
\end{tabular}

Table 12. servir 'serve', Val d'Aran (Carrera 2007: 189). Forms with an augment are shaded (-iss- in mid grey, -isc- in dark grey, -ig- in light grey). In the lower valley, note PFV.PST.IND serví, servís, servíc, servírem, servíretz, servíren; IPFV.SBJV servissa, servisses, servisse, servíssem, servíssetz, servissen.

Most variegated of all is the system claimed for the single survey point Caychax (ALLOc 09.31, Table 13). The ALLOc transcription (subsequently reported in Ravier 1970) attests six separate augments in regular second-conjugation verbs: -eish- and -esc- in the N-pattern cells of the PRS.IND and PRS.SBJV respectively. -ish- and -isqu- in the 1PL and 2PL cells of the PRS.IND and PRS.SBJV respectively, -issthroughout the IPFV.PST.IND and -ig-in the PFV.PST.IND. It is regrettable that the ALLOc data, which are the only known source for this locality, do not include IPFV.SBJV forms within the otherwise complete secondconjugation model bastir 'build'; though the partial paradigms given for other second-conjugation verbs, such as lhegir 'read', morir 'die', derbir 'open' indicate (etymological) -iss- for the IPFV.SBJV, as is the case in the nearby varieties of Siguer (ALLOc 09.22), Massat (Laurent 2001: 30-32) and many varieties spoken in Gascony. The source of the formative -ig- in the PFV.PST.IND of Caychax and Siguer is discussed further in $\S 4.2$.

Some elements of this paradigm are in fact common to other varieties of the area. The alternation between -esc- and -isc- in the PRS.SBJV is also found in the varieties of Massat (Laurent 2001: 30) and Aulus (Laurent 2002: 28); in both these varieties, and in that of Quérigut (ALLOc 09.33), -eish-in the PRS.IND is restricted to the N-pattern. Massat and Aulus differ from Caychax in having no augment in 1PL.PRS.IND and 2PL.PRS.IND, but Quérigut has -iss-. Merens-les-Vals (ALLOc 09.32) has -ig-throughout the PFV.PST.IND (-ic in 3SG), but -eish- throughout the PRS.IND, PRS.SBJV, IPFV.PST.IND and IPFV.SBJV. The 2PL.IMP forms (usually syncretic with 2PL.PRS.IND) bastissètz 'build!' and lhegissètz/degissètz 'read!') elicited for Caychax in the ALLOc survey, together with 3SG.IPFV.PST.IND degishiá 'read.3SG.PST.IPFV.IND' may indicate free variation between -ish- and -iss- in the 1PL.PRS.IND and 2PL.PRS.IND (few varieties of Occitan have a phonemic opposition between /s/ and / / / ), which reduces the number of augments by one and also restores the common identity of stem between 1PL.PRS.IND, 2PL.PRS.IND and the IPFV.PST.IND. 
Preprint of: Esher, Louise. 2016. Morphomic distribution of augments in varieties of Occitan. Revue Romane 51(2). 271-306.

\begin{tabular}{|c|c|c|c|c|c|c|c|}
\hline & PRS.IND & IPFV.PST.IND & PRS.SBJV & PFV.PST.IND & IPFV.SBJV & FUT & COND \\
\hline $1 \mathrm{SG}$ & basteishi & bastissiá & bastesca & bastigui & & bastiré & bastirá \\
\hline $2 \mathrm{SG}$ & basteishes & bastissiás & bastescas & bastigues & & bastiràs & bastirás \\
\hline $3 \mathrm{SG}$ & basteish & bastissiá & bastesca & bastic & & bastirà & bastirá \\
\hline 1PL & bastishèm & bastissián & $\begin{array}{l}\text { bastisquiam } \\
\text { bastisquem }\end{array}$ & bastiguem & & bastirem & bastirám \\
\hline 2PL & bastishètz & bastissiátz & bastisquiatz & bastiguetz & & bastiretz & bastirátz \\
\hline 3PL & bastéishen & bastissián & $\begin{array}{l}\text { bastescan } \\
\text { bastesquion }\end{array}$ & bastiguen & & bastiràn & bastirán \\
\hline
\end{tabular}

Table 13. bastir 'build', Caychax (ALLOc 09.31). IPFV.SBJV forms are not given in the ALLOc transcription. Forms with an augment continuing -ESC- are shaded (-eish-in mid grey, -esc- in dark grey), as are forms presenting the string -ig- (light grey).

The sample paradigms shown here serve to illustrate the diversity exhibited by Occitan secondconjugation verbs, concerning both the range of augments present, and the paradigmatic distribution of these augments. The diversity of distribution reflects the fact that the augments lack morphosemantic or morphosyntactic feature content: they are arbitrary formatives, which can potentially be distributed through the paradigm in many arbitrary ways. To some extent, the distribution of augments reflects their historical incidence: they are most commonly found in the paradigm categories continuing infectum forms (see Meul 2013: 91), and the allomorphs -isc-/-esc- resulting from conservation of velars before non-front vowels tend to remain confined to the PRS.SBJV where they originated. In other respects, the modern distributions testify to extensive analogical change, such as the spread of -iss- throughout the paradigm in the varieties of Nice, or the restriction of -eish- to N-pattern forms. There is, however, one constant: the reflexes of -ĩSC- and ESC- are always redistributed in accordance with existing, morphomic templates for stem allomorphy, whichever templates they exploit, and whichever augments are assigned to each.

In this respect, the distribution of augments recalls the distribution of many other types of inflectional alternation. It is well documented (see e.g. Maiden 2009b, 2011b) that, in Romance, novel alternations arising through defectiveness, suppletion, heteroclisis and analogy are systematically distributed according to metamorphomic patterns. This recurrent tendency has led Maiden (2013) to suggest that metamorphomes may have a function in acquisition, as a means of predictably organising arbitrary inflectional alternations. Under this view, metamorphomic templates effectively provide a strategy for resolving the 'Paradigm Filling Problem' identified by Ackerman et al. (2009: 54): if inflectional alternations, whatever their content, consistently follow a given template of paradigmatic distribution, speakers can draw more reliable inferences about the forms which realise different cells of the paradigm.

The data also indicate a correlation between inflectional class marking and the paradigmatic distribution of augments. Today, the reflexes of -īSC- and -ËSC- only exist as inflectional formatives within the second conjugation, ${ }^{24}$ and the spread of augments through the paradigm shows some degree of

${ }^{24}$ A continuant of the formative -SC- can also be identified in some third-conjugation verbs, such as créisser 'grow', paréisser 'appear', nàisser 'be born'. These items are few, and the diverse analogical changes which they undergo indicate that they are not perceived as a coherent subclass (Esher 2012a). 
Preprint of: Esher, Louise. 2016. Morphomic distribution of augments in varieties of Occitan. Revue Romane 51(2). 271-306.

correlation with the loss of conjugational class distinctions in the desinences. Thus the templates for the distribution of augments concern two different types of morphomic object: in the terminology of Round (2015), both 'metamorphomes' (systematic paradigmatic distributions), and 'rhizomorphomes' (inflectional classes).

\section{Augments in PYTA}

Across much of the Occitan-speaking area, as the inflectional patterns in Tables $8-13^{25}$ show, regular second-conjugation verbs display an inflectional formative within PYTA which resembles the -İSCaugment in its phonological content, and in the position which it occupies between the lexical root and the desinence. In some cases, the formative found in PYTA is indeed a reflex of -īSC-, while in others it is a novel item resulting from analogy with formatives found in other conjugational types. The difference between the two is highlighted by a contrast between the two sub-classes of the second conjugation in Occitan: the large and productive class IIa, members of which display an augment in the reflexes of infectum forms $^{26}$, and the much smaller, closed, class IIb, members of which have no augment in the reflexes of infectum forms.

In the eastern systems illustrated in Tables 7 and 8, lexemes of class IIa have a single augment iss- throughout the majority of the paradigm, whereas lexemes of class IIb have no augment in any form. In several varieties with systems of the type illustrated in Tables 10-11, such as Paulhan (ALLOr 34.07E) the distinction between IIa and IIb is not made; all second-conjugation lexemes inflect according to the same pattern. However, in varieties in which (1) a distinction between IIa and IIb is made, and (2) IIa lexemes inflect according to a pattern of the type illustrated in Tables 9-11, lexemes of both classes display the same augment-like formative in PYTA. Thus, in the variety of Clermont-le-Fort (ALLOc 31.20), the PYTA forms of IIb lexemes such as sortir 'go out', dromir 'sleep', partir 'leave' and morir 'die' present the same formative, -/isk/-, as the PYTA forms of IIa bastir 'build' and legir 'read' (Table 14). Likewise, the PYTA forms of augmentless second-conjugation verbs in Provence and the Limousin commonly present a string -ig- (Martin \& Moulin 2007: 95-100, Roux \& Lévêque 2011: 35-41). Note, however, that the PRS.SBJV of IIb lexemes appears to lack the formative /isk/ found in the PRS.SBJV of IIa lexemes. ${ }^{27}$ The absence of any such formative from the PRS.SBJV of IIb lexemes means that /isk/ (or /ig/) in PYTA cannot be attributed to direct analogical extension from the PRS.SBJV to PYTA. In the following section, I propose an alternative explanation for the source of the augment-like formative in PYTA.

\footnotetext{
${ }^{25}$ I include Table 11 as the formative /i/ within PYTA is historically derived from the ig-augment.

${ }^{26}$ With the exception of the INF, which I exclude from consideration due to its separate status within the paradigm (see Bach \& Esher 2015 for discussion).

${ }^{27}$ The ALLOc transcription for Clermont suggests that -/isk/- may be present in 1PL.PRS.SBJV and 2PL.PRS.SBJV; however, as the source only contains partial paradigms, which frequently do not include these forms, such a claim cannot be made with certainty.
} 
Preprint of: Esher, Louise. 2016. Morphomic distribution of augments in varieties of Occitan. Revue Romane 51(2). 271-306.

\begin{tabular}{llllllll}
\hline & PRS.IND & IPFV.PST.IND & PRS.SBJV & PFV.PST.IND & IPFV.SBJV & FUT & COND \\
\hline BASTIR & bastís & bastissiá & bastisca & bastisquèc & bastisquèssa & bastirà & bastiriá \\
LEGIR & legís & legissiá & legisca & legisquèc & legisquèssa & legirà & legiriá \\
— & sòrt & sortiá & sòrta & sortisquèc & sortisquèssa & sortirà & sortiriá \\
DROMIR & dròm & dromiá & dròmia & dromisquèc & dromisquèssa & dromirà & dromiriá \\
PARTIR & part & partiá & parta & partisquèc & - & partirà & partiriá \\
MORIR & mòr & moriá & mòria & morisquèc & morisquèssa & morirà & moririá \\
\hline
\end{tabular}

Table 14. 3SG forms of class IIa and IIb lexemes, Clermont-le-Fort (ALLOc 31.20). Forms presenting an augment are shaded (-iss- in dark grey, -isc- in lighter grey). Note that the INF of sòrt and the IPFV.SBJV of partir are missing from the $A L L O c$ transcription.

\subsection{Velar formatives as markers of PYTA}

In many varieties of Occitan (\$2.2), the PYTA forms of most irregular lexemes present a velar formative /g/ (realised [y] in some varieties) or /sk/. These formatives arise by regular sound change, and are subsequently redistributed by analogy. As with the augments continuing -İSC- and -ĒSC-, the lexical extent of velar formatives is subject to extensive regional variation. In Gascony, velar formatives are rare, and /sk/ is predominant; in the Languedoc, both /sk/ and /g/ are found, largely confined to irregular verbs; and in some varieties of the north-east Languedoc, Auvergne and Provence, a velar $/ \mathrm{g} /$ is present in all regular third-conjugation verbs (see e.g. Camproux 1962, Moulin 2006, Martin \& Moulin 2007: 101-102).

The variation between /g/ and /sk/ has both lexical and dialectal axes. Many Languedoc varieties present both $/ \mathrm{g} /$ and $/ \mathrm{sk} /$, but with a preference for one or the other. In the variety of Rabastens (ALLOc 81.06), for example, most irregular PYTA forms have /g/, as exemplified by the following 3SG.PST.PFV.IND forms: anguèt 'went', faguèt 'did', coneguèt 'knew', correguèt 'walked', creisseguèt or cresquèt 'grew', coseguèt 'cooked', poguèt 'was able', tenguèt 'held', nasquèt 'was born', valguèt 'was worth', volguèt 'wanted', visquèt 'lived', calguèt 'it was necessary'. By contrast, in the variety of Clermont-le-Fort (ALLOc 31.20) a higher proportion of irregular PYTA forms have /sk/ than in Rabastens (compare Clermont 3SG.PST.PFV.IND forms anguèc 'went', fasquèc 'did', conesquèc 'knew', corguèc 'walked', creshèc or cresquèc 'grew', posquèc 'was able', tenguèc 'held', nasquèc 'was born', valguèc 'was worth', volguèc 'wanted', visquèc 'lived', calguèc or carguèc 'it was necessary'). As these examples illustrate, some lexemes are stable as to which velar formative they present: nàisser 'be born' and viure 'live' are not found with PYTA roots in /g/, while tenir 'have', venir 'come', voler 'want' and valer 'be worth' are not found with PYTA roots in /sk/. Others, such as créisser 'grow' and far 'do', present/g/ in some varieties and /sk/ in others. Most of the lexemes considered here can be found with velarless PYTA roots somewhere in the Occitan-speaking area, particularly in the most south-westerly and south-easterly areas.

In the examples described above, any realised wordform has a maximum of one velar formative: thus for the preterite of créisser 'grow' in Rabastens, a speaker may produce creisseguèt or cresquèt, but not e.g. *cresqueguèt with both/sk/ and /g/. For the varieties of the Gévaudan (in the north-east Languedoc), however, Ronjat (1937: 323) and Camproux (1962: 439-440) note forms such as nasqueguére 'I was born', visqueguére 'I lived' conesqueguére 'I knew', posqueguére 'I was able'. Such hybrid forms exist alongside their /g/-less equivalents nasquére, visquére, conesquére and posquére, indicating that $/ \mathrm{g} /$ has spread into 
Preprint of: Esher, Louise. 2016. Morphomic distribution of augments in varieties of Occitan. Revue Romane 51(2). 271-306.

the PYTA forms of the lexemes in question without replacing /sk/; in these cases, speakers have conceivably analysed /sk/ as part of the lexical root, rather than as an augment. ${ }^{28}$ Camproux (1962: 440) also notes that in this area $/ \mathrm{g} /$ is being extended into first-conjugation verbs, e.g. escoteguét 'listen.3SG.PST.PFV.IND' for original escotét: effectively, /g/ is becoming a generalised marker of PYTA across conjugations.

\subsection{Velar + theme vowel}

In a number of varieties, velar formatives are also found in the PYTA forms of second-conjugation verbs, where they are not etymological. These formatives show regional variation between -isc- and -ig- which correlates with the regional variation between /sk/ and /g/ in the PYTA forms of third-conjugation lexemes. In Rabastens, where /g/ is dominant in the third conjugation, the formative found in second-conjugation PRS.SBJV and PYTA forms is -ig-, e.g. moriguèt 'die.3SG.PST.PFV.IND'; whereas in Clermont, where /sk/ is dominant, the second-conjugation formative is -isc-, as in morisquèc. Furthermore, in varieties such as that of Pampelonne, where /g/ was historically dominant but has lenited and deleted in intervocalic position, the second-conjugation formative is simply /i/, without a velar element. The parallels in paradigmatic and regional distribution indicate that the second-conjugation formatives -ig- and -isc-are closely associated with the third-conjugation velar formatives. Since the latter can be shown to be etymological in some paradigm cells and lexemes, spreading to other third-conjugation lexemes by analogy (\$2.2), and since velar formatives appear in the third conjugation before the second conjugation (as in the forms given by Skårup 1997), it may be deduced that the velar is introduced into second-conjugation PYTA forms on analogy with third-conjugation PYTA forms.

It should be noted that there are some important differences in the lexical and paradigmatic distributions of the second- and third-conjugation PYTA formatives. In the third conjugation, there are two formatives, either or both of which may occur in a subset of lexemes or throughout the class; whereas in the second conjugation, there is a single formative, which occurs systematically in all lexemes. Furthermore, in the second conjugation, the velar formative always occurs in conjunction with the distinctive theme vowel /i/: thus e.g. floriguèt 'it flowered' and florisquèc are attested, but not *florguèt or *florguèc without a theme vowel, or indeed *floreguèt or *floresquèc with the vowel /e/ (in contrast to coneguèt, etc. cited above).

\footnotetext{
${ }^{28}$ Note also the development observed in some neighbouring varieties of the Auvergne, in which a formative -peoriginating in the reflex of SAPERE is spread through the PYTA forms of irregular verbs alongside the generalised PYTA marker -guè-; hence e.g. viupeguèri 'I lived', saupeguèri 'I knew', deupeguèri 'I had to'. In these varieties guè- is systematic throughout the PYTA forms of regular third-conjugation verbs (Moulin 2006).
} 
Preprint of: Esher, Louise. 2016. Morphomic distribution of augments in varieties of Occitan. Revue Romane 51(2). 271-306.

\begin{tabular}{lll}
\hline & PFV.PST.IND & IPFV.SBJV \\
\hline 1SG & parti & partis \\
2SG & partist & partis \\
3SG & parti, partit, partic & partis \\
1PL & partim & partissém \\
2PL & partitz & partissétz \\
3PL & partiron, partiren & partisson, partissen \\
\hline
\end{tabular}

Table 15. Partial paradigm for mediaeval Occitan partir 'leave’' Skårup 1997: 112,120).

It is possible that the theme vowel survives from the mediaeval PYTA forms, in which it was systematically present due to regular sound change; Skårup (1997: 112,120) gives the sample paradigm in Table 15. The final velar of the 3SG.PFV.PST.IND in some mediaeval varieties, included in the table, is attributed to analogy with strong perfects such as ac 'had', and sometimes spreads throughout the PFV.PST.IND, resulting in forms such as cobrigui 'I covered' (Ronjat 1937: 179). These forms are known from the fourteenth-century Toulousain grammar Las Leys d'Amors (Anglade 1919), which proscribes them, together with first- and third-conjugation PFV.PST.IND forms in which the velar also occurs throughout. In fact, the examples given in the Leys are strongly reminiscent of several modern varieties of the area of Toulouse and Foix (including Caychax in Table 13), in which all PFV.PST.IND forms present a velar. This type is discussed by Ronjat (1937: 192) and also by Bybee \& Brewer (1980), the latter ascribing it to remodelling of all PFV.PST.IND forms on the 3SG.

But forms of the type shown in Table 16, despite showing a systematic presence of velar formatives in the PFV.PST.IND in all conjugations, do not provide a satisfactory explanation for the formatives which are the main concern of this study. The system shown in Table 16 is geographically restricted, so is unlikely to explain distributions found elsewhere. More importantly, the velar $/ \mathrm{k} /$ or $/ \mathrm{g} /$ is confined to the PFV.PST.IND, rather than being a generalised marker of PYTA, shared with the IPFV.SBJV; and alongside florigui Ronjat cites florisquègui, which indicates that the presence of a sequence -ig-does not block the introduction of -sk-. Indeed, the behaviour of - $\mathrm{g}$ - in this area more closely recalls that of the generalised preterite marker -r-, which Ronjat also attests as existing in this area (cantèri, cantères, cantèc, etc.). The forms florisquègui, etc. must result from the simultaneous generalisation of the vowel $/ \varepsilon /$ to all PFV.PST.IND forms (which consequently share a sequence $/ \varepsilon \mathrm{g} /$ ), the introduction of the PYTA marker /sk/, and the retention of the second-conjugation theme vowel $/ \mathrm{i} /$. 
Preprint of: Esher, Louise. 2016. Morphomic distribution of augments in varieties of Occitan. Revue Romane 51(2). 271-306.

\begin{tabular}{lllll}
\hline & PFV.PST.IND, I & PFV.PST.IND, II & or alternatively & PFV.PST.IND, III \\
\hline $1 \mathrm{SG}$ & cantègui & florigui & florisquègui & batègui \\
$2 \mathrm{SG}$ & cantègues & florigues & florisquègues & batègues \\
$3 \mathrm{SG}$ & cantèc & floric & florisquèc & batèc \\
$1 \mathrm{PL}$ & cantèguem & floriguem & florisquèguem & batèguem \\
$2 \mathrm{PL}$ & cantèguetz & floriguetz & florisquèguetz & batèguetz \\
$3 \mathrm{PL}$ & cantèguen & floriguen & florisquèguen & batèguen \\
\hline
\end{tabular}

Table 16. Preterite types for Foix and surrounding area, adapted from Ronjat (1937: 192) who gives only the desinences.

The retention of the theme vowel in PYTA, in contrast to what happens in other classes, is plausibly explained by the presence of this theme vowel in all wordforms of IIa lexemes. Whereas in class III there is no theme vowel, and in class I the original theme vowel /a/ occurs in only a subset of wordforms (and with varying phonological realisations), in class IIa all wordforms present a theme vowel with the quality /i/. The presence of the theme vowel in all non-PYTA forms of a IIa lexeme allows the vowel to be analysed as part of the lexical root. If the vowel /i/ etymologically present within PYTA is so analysed, it will be less susceptible to replacement by $/ \varepsilon /$ on analogy with the PYTA forms in other conjugations. This explanation is supported by the fact that varieties such as those of Massat (Laurent 2001), Béarn (Grosclaude \& Nariòo 1998) and Siguer (ALLOc 09.22), which present a reflex of -ESC- elsewhere in the IIa paradigm, do not present a velar throughout the PYTA forms of IIa lexemes, but only within the PFV.PST.IND, if at all.

I therefore suggest that the second-conjugation formatives -ig- and -isqu- arise as novel items, combining the vowel /i/ already present in the PYTA forms of second-conjugation lexemes, and the distinctive velar formative associated with the metamorphome PYTA. A further advantage of this explanation is that it avoids appeal to any independent motivation for maintaining the distinction between II and other classes, as such motivation proves difficult to identify ( $\$ 5$ below).

The appearance of -ig- and -isqu- in IIb lexemes cannot be explained by exactly the same mechanism, since / $\mathrm{i} /$ is not present in all wordforms. Instead, a further analogy between the PYTA forms of IIa and IIb lexemes must be assumed. Both IIa and IIb lexemes have /i/ in PYTA and in Fuèc, but IIa lexemes are of higher lexical type frequency than IIb lexemes; thus IIa lexemes are a good model for structured analogy to extend to IIb lexemes (compare Albright 2009), and as IIa lexemes systematically have a velar in PYTA, this is spread to the IIb type.

\subsection{Sometimes the augment really is one}

The behaviour described for -isc-/-ig-contrasts with that of the formative -iss-found in PYTA in the Provençal variety illustrated in Table 7. In this variety, and in that of Nice, IIb lexemes have no augment at all in PYTA, and thus no inflectional formative within PYTA which would indicate that the form belongs to a second-conjugation lexeme (consider e.g. partèri 'I left', culhèri 'I gathered', morèri 'I died', Martin \& Moulin 2007: 95,97,99). The phonological shape of the augment -iss-found in the PYTA forms of IIa lexemes in this variety also contrasts with a preference for the formative $/ \mathrm{g} /$ (over -sc- or $*_{-} s s_{-}$) in the PYTA forms of third-conjugation lexemes. As this variety has generalised desinences with the theme vowel $\grave{e}$ 
Preprint of: Esher, Louise. 2016. Morphomic distribution of augments in varieties of Occitan. Revue Romane 51(2). 271-306.

throughout PYTA, the formative -iss- cannot be considered to continue the etymological -İSS- of the IPFV.SBJV (compare varieties in Ariège, Gascony and the Val d'Aran where etymological -İSS- is continued; -iss- < -İSS- never co-occurs with -èss- in a given IPFV.SBJV form). Instead, in this variety as in those of Nice, the augment found in PYTA does indeed continue -ISSC- and results from analogical extension of -iss$<-$ ISC- through the paradigm.

\section{Augments as morphomic markers}

\subsection{Augments and the neutralisation of inflectional class distinctions}

For Francoprovençal and Italo-Romance, Meul (2013: 104-122) shows that paradigmatic extension of the augment is associated with neutralisation of conjugational class distinctions. A similar observation may be made for the Occitan varieties considered here: the most restricted distribution of augments is found in Gascon varieties which conserve a three-way class distinction in almost all paradigm categories, while the most extensive distribution is found in the area of Nice, where distinction between classes II and III has entirely collapsed in finite forms (see Dalbera 1994: 598,620).

The trends observed are illustrated by Tables 17-20, which show 3SG forms for all finite paradigm categories in four of the varieties discussed in $\$ 3$, for verbs traditionally classed as belonging to conjugations I, IIa, IIb and III. ${ }^{29}$ Augmented forms are shaded; forms which, independently of the augment, are unambiguously marked as belonging to a single one of the three major conjugations (whether I, II or III) are outlined in bold. I exclude non-finite forms from consideration here, as peripheral to the paradigm (see Bach \& Esher 2015 for the separate status of the INF; similar arguments may be adduced for the PST.PTCP).

In standard Gascon (Table 17), an augment is present only within the PRS.IND and PRS.SBJV, which are the only finite categories not to make a three-way distinction; in all other categories, each of the three major classes is identified unambiguously by a theme vowel or desinence. By contrast, in the variety of Clermont-le-Fort (western Languedoc; Table 18) and in standard Provençal (Table 19), augments are also found in PYTA (where conjugation class has been entirely neutralised), and in the IPFV.PST.IND, where only class I is unambiguously identified. In Nice (Table 20), where conjugation class has also been entirely neutralised in Fuèc, an augment is found throughout the paradigm of class IIa verbs. ${ }^{30}$

\footnotetext{
${ }^{29}$ Continuing Latin conjugations I, IV (ingressive), IV (non-ingressive) and III respectively.

${ }^{30}$ The sole exceptions are the INF (for which see Bach \& Esher 2015), and the PST.PTCP (which commonly has an idiosyncratic form). The treatment of the augment is significant for the description of the conjugation class system in this variety: if the augment is considered an inflectional class marker, class IIb can be analysed as having merged with III, while IIa remains distinct; whereas if the augment is not considered a marker of inflectional class, conjugations IIa, IIb and III can be collapsed into a single class. Martin Maiden (p.c.) points out that the question of whether the augment in Nice is indeed an inflectional class marker is logically independent of whether it should be analysed as part of the lexical root.
} 
Preprint of: Esher, Louise. 2016. Morphomic distribution of augments in varieties of Occitan. Revue Romane 51(2). 271-306.

\begin{tabular}{l|l|lllllll|}
\hline \multicolumn{2}{l}{ PRS.IND } & \multicolumn{1}{l}{ IPFV.PST.IND } & PRS.SBJV & PFV.PST.IND & IPFV.SBJV & FUT & COND \\
\hline I & canta & cantava & cante & cantè & cantèsse & cantarà & cantaré \\
\cline { 2 - 6 } IIa & causeish & causiva & causesca & causí & causisse & causirà & causiré \\
IIb & sent & sentiva & séntia & sentí & sentisse & sentirà & sentiré \\
\cline { 5 - 8 } III & bat & batèva & bàtia & bató & batosse & baterà & bateré \\
\hline
\end{tabular}

Table 17. Standard Gascon. Data from Romieu \& Bianchi (2005). Forms with an augment are shaded.

\begin{tabular}{|c|c|c|c|c|c|c|c|}
\hline & PRS.IND & IPFV.PST.IND & PRS.SBJV & PFV.PST.IND & IPFV.SBJV & FUT & COND \\
\hline I & canta & canta(v)a & cante & cantèc & cantèssa & cantarà & canta(r)iá \\
\hline IIa & bastís & bastissiá & bastisca & bastisquèc & bastisquèssa & bastirà & basti(r)iá \\
\hline $\mathrm{IIb}$ & sòrt & sortiá & sòrta & sortisquèc & sortisquèssa & sortirà & sortir(i)á \\
\hline III & $\operatorname{ven}(d)$ & vendiá & venda & vendèc & vendèssa & vendrà & vendr(i)á \\
\hline
\end{tabular}

Table 18. Clermont-le-Fort. ALLOc 31.20. Forms with an augment are shaded.

\begin{tabular}{|c|c|c|c|c|c|c|c|}
\hline & PRS.IND & IPFV.PST.IND & PRS.SBJV & PFV.PST.IND & IPFV.SBJV & FUT & COND \\
\hline I & parla & parlava & parle & parlèt & parlèsse & parlarà & parlariá \\
\hline IIa & finisse & finissiá & finisse & finissèt & finissèsse & finirà & finiriá \\
\hline $\mathrm{IIb}$ & parte & partiá & parte & partèt & partèsse & partirà & partiriá \\
\hline III & bate & batiá & bate & batèt & batèsse & batrà & batriá \\
\hline
\end{tabular}

Table 19. Provence (Martin \& Moulin 2007: 89-102). Forms with an augment are shaded.

\begin{tabular}{|c|c|c|c|c|c|c|c|}
\hline & PRS.IND & IPFV.PST.IND & PRS.SBJV & PFV.PST.IND & IPFV.SBJV & FUT & COND \\
\hline I & canta & cantava & cante & cantèt & cantesse & canterà & canteria \\
\hline IIa & finisse & finissia & finisse & finissèt & finissesse & finisserà & finisseria \\
\hline $\mathrm{IIb}$ & parte & partia & parte & partèt & partesse & parterà & parteria \\
\hline III & bate & batia & bate & batèt & batesse & baterà & bateria \\
\hline
\end{tabular}

Table 20. Nice (Toscano 1998: 100-103). Forms with an augment are shaded.

Meul (2013: 118-122) explains such correlation by presenting the paradigmatic extension of augments as a device for maintaining conjugational class distinctions. Under this view, the augment is a conjugational class marker with similar status to a thematic vowel (an analysis supported by the complementary distribution of the reflex of -ËSC-/-ISC- and the theme vowel /i/ within individual paradigms). Such an analysis implicitly assumes that there is some advantage to keeping IIa separate from other classes; yet no clear motivation to do so is offered by existing work on inflectional class systems.

The most familiar constraint on inflectional classes, the 'No Blur Principle', or 'Vocabular Clarity' (see e.g. Carstairs-McCarthy 1994, Enger 2012 for discussion), sets an upper limit for the complexity of an 
Preprint of: Esher, Louise. 2016. Morphomic distribution of augments in varieties of Occitan. Revue Romane 51(2). 271-306.

inflectional class system. The principle states that any given affix must either be specific to one inflectional class, or must be a default: it is effective in accounting for the relatively low number of classes found in a language, out of the wide range of logical possibilities, but it imposes no minimum level of complexity. In the particular case of the Occitan systems described above, the absence of an augment would not cause any violation of the No Blur Principle, since for any given paradigm category, either all conjugations would present the default affix, or all conjugations except I would present the default affix. The No Blur Principle cannot therefore be invoked as motivation for keeping IIa separate from other classes.

An alternative constraint is the 'Low Entropy Conjecture' proposed by Ackerman \& Malouf (2013). According to this hypothesis, a language may display a complex inflectional system with many different exponents and inflectional classes, provided that the system has low conditional entropy, entropy being 'a measure of the reliability of guessing unknown forms on the basis of known ones' (2013: 436). Some systems have low conditional entropy simply because they only involve a small range of items to choose from: few inflectional classes, few exponents and few morphosyntactic features (2013: 445). Others involve many classes, exponents and/or features, but nevertheless have low conditional entropy because they are structured in such a way that knowledge of one form permits inferences about other forms. For instance, in the modern Greek example discussed by Ackerman \& Malouf (2013: 440), the feature combinations ACC.PL and GEN.SG each have five possible exponents, but only 7 of the 25 logically possible pairings between these exponents are found in the lexicon. A speaker who hears an ACC.PL form in $-i$ for a given lexeme can predict with certainty that the GEN.SG form of that lexeme is in -us; a speaker who hears an ACC.PL form in - $a$ cannot immediately tell whether the GEN.SG form of that lexeme is in - $u$ or -os, but does know that it will be one of the two, rather than any of the other three GEN.SG inflections. Such systems, in which forms are predictable from other forms, are 'learnable and efficiently usable by native speakers' (2013: 436). Since languages evolve via cultural transmission and iterated learning, language change is subject to speakers' learning biases (see e.g. Kirby et al. 2014 for discussion); one might therefore assume that more learnable systems would be favoured over less learnable systems, and thus that diachronic change is likely to tend towards lower, rather than higher, conditional entropy.

Returning to the Occitan data, Languedoc varieties such as that of Paulhan, in which there are no lexemes of class IIb, have a highly predictable paradigm for second-conjugation verbs. In these varieties, the theme vowel /i/ and the -ESSC-/-ISC- augment are both confined to a single class, and all wordforms for a lexeme of that class present one or other formative; thus a speaker only has to hear one form of a novel second-conjugation lexeme to predict all the others correctly (and, indeed, only one form of any lexeme to divine whether it is a second-conjugation lexeme or not). In other varieties, the existence of IIb compromises interpredictability to some extent. In the system shown in Table 19, for example, the presence of an -ËSC-/-İSC- augment in any form predicts with 100\% accuracy that FUT and COND forms have theme vowel /i/, whereas the presence of theme vowel /i/ in a FUT or COND form does not predict whether the other forms of the lexeme have an -ËSC-/-İSC- augment or not. In a variety such as that of Table 18, where the PYTA augment is present in both IIa and IIb lexemes, the PYTA augment and theme vowel /i/ in Fuèc are perfectly interpredictable, whereas neither the PYTA forms nor the Fuèc forms reliably predict the forms found in the PRS.IND, IPFV.PST.IND and PRS.SBJV. These systems still have relatively low entropy, ${ }^{31}$ due to

${ }^{31}$ Cf. heuristic values computed for these paradigms by the Principal Parts Analyzer (version 3.19), developed by G. Stump and R. Finkel (University of Kentucky); the measures are discussed in Stump \& Finkel (2013). These figures should not be taken as representative of verb conjugation in general, since they are based on a data set which contains 
Preprint of: Esher, Louise. 2016. Morphomic distribution of augments in varieties of Occitan. Revue Romane 51(2). 271-306.

the consistency of the metamorphomic templates. The most predictable system, though, is that of Nice (Table 20), which effectively reduces to two classes; conceivably a case of reducing entropy through reducing the range of possible choices. Once again, the data show no clear motivation for keeping IIa separate from other classes.

Finally, Enger (2014) presents data to the effect that, where distinct inflectional classes are maintained, they can become 'reinforced', with multiple distinctive markers. Based on these findings, one might expect that the augment would co-occur with an existing marker of IIa, or that a more general marker would become restricted to IIa; but there is no evidence for such a development.

Overall, the spread of augments through the paradigm has the result that an inflection class distinction is maintained without being reinforced and without significantly improving the interpredictability of the paradigm.

\subsection{Marking metamorphomes and rhizomorphomes}

The data in Tables 6-13 illustrate the distribution of augments, which occurs consistently with metamorphomic templates. In the most restricted distribution, that of Béarn, augments are confined to the $\mathrm{N}$-pattern and (what remains of) the L-pattern. In the Val d'Aran, reflexes of -ĩSC- are confined to the Npattern, which overlaps with the morphome resulting from fusion of PYTA with the L-pattern/PRS.SBJV, and the distribution of a second augment, -ig-, occurs through this extended variant of PYTA; no augment is found in the morphome Fuèc, consisting of the Romance synthetic FUT and COND, or in the set of cells \{IPFV.PST.IND, 1PL.PRS.IND, 2PL.PRS.IND which comprises the remaining reflexes of infectum forms after the subtraction of the N-pattern and PRS.SBJV. In the Languedoc, the presence of a single augment, whatever its form, throughout PYTA, and the absence of augments in Fuèc, are constants. In Provence, where the reflex of -İSC- spreads into PYTA (an area of the paradigm in which it was not present either in Latin or in mediaeval Occitan), it spreads throughout PYTA; and in Nice, where the the reflex of -İSC- spreads into Fuèc (another area from which it was originally absent), it spreads throughout Fuèc. The relationship of augments with the second-conjugation theme vowel/i/ indicates that both function as inflectional class markers, i.e. exponents of rhizomorphomes; the extension of these markers through the paradigm occurs in steps consisting of whole metamorphomes. ${ }^{32}$ Furthermore, augments are not the only inflectional class markers with a paradigmatic distribution constrained by metamorphomes. In Table 17 (standard Gascon), for example, all three major classes are uniquely distinguished by a theme vowel in PYTA and in Fuèc. For any given class, the same theme vowel is found through all constituent cells of a given morphome; but the

only the four conjugational types illustrated, and which ignores root allomorphy; nevertheless, they provide an indication of the relative complexity of the different systems. For example, average inflection class predictability (the proportion of principal part sets adequate to identify a lexeme's inflection class membership, varying between 0 to 1) ranges from 0.643 (Clermont) through 0.667 (Nice, Gascony) to 0.679 (Provence); while the average uncertainty as to a lexeme's inflection class membership, given a subset of its cells, ranges from 0.2 (Nice) through 0.23 (Clermont, Provence) to 0.34 (Gascony). The range of values on each measure is small, and no general ranking of varieties for predictability emerges overall.

${ }^{32}$ As in Maiden's (2009b) analysis of incipient heteroclisis in Romanian verbs, where neutralisation of the distinction between first-conjugation exponence and fourth-conjugation exponence first occurs in a subset of paradigm cells, and its subsequent spread to other cells is constrained by existing metamorphomic templates. 
Preprint of: Esher, Louise. 2016. Morphomic distribution of augments in varieties of Occitan. Revue Romane 51(2). 271-306.

theme vowels available to the two morphomes are different: / / / vs. /i/ vs. /u/33 in PYTA, /a/ vs. /i/ vs. /e/ in Fuèc.

The neutralisation of conjugation class in inflectional formatives is, in a sense, an example of 'convergence' (Maiden 2011a: 118). Convergence may be defined as the tendency for lexemes to share a common exponent for a given metamorphome; it is usually diagnosed when this exponent is analogically spread into lexemes where the presence of the exponent cannot be attributed to etymology or regular sound change. Convergence was initially exemplified from irregular lexemes with extensive stem allomorphy: for instance, distinctive PYTA roots in Castilian are often characterised by a high vowel (Maiden 2001, 2005), and in Italo-Romance by a root-final geminate (Maiden 2011a: 198), while distinctive Fuèc stems in Occitan often present the sequence $-d r$ - (Esher 2012a, 2012b). However, there is no principled reason for the phenomenon of convergence to be restricted to irregular lexemes, and indeed the Occitan data discussed here indicate that convergence can also affect regular lexemes. In the variety of Nice, for example, the spread of the theme vowel /e/ across all Fuèc forms in all lexemes results in all Fuèc forms being uniquely identified by the sequence /er/. ${ }^{34}$ The spread of the characteristic velar found in the PYTA forms of Occitan verbs is another instance of convergence: as in the cases described by Maiden, the Occitan velar originates in a small number of high-token-frequency irregulars, but it ends up, as in Nice, occurring systematically in at least one class of regular lexeme. The interest of these developments to the present study is that both the Fuèc marker /er/ and the PYTA marker $/ \mathrm{g} / \sim / \mathrm{sk} / \mathrm{spread}$ through the lexicon one conjugational class at a time. In Nice and surrounding varieties, the Fuèc marker begins in the first conjugation, spreading from there into classes III and IIb, and finally into IIa (Esher 2012a). For PYTA, the initial locus of the velar formative is a subset of third-conjugation verbs; in many varieties, it subsequently spreads to a coherent set of second-conjugation verbs (either all IIa verbs, or all verbs of class II, both IIa and IIb); in some, to all third-conjugation verbs; and in others still, most rarely, into the first conjugation.

Together, augment spread and convergence indicate that the marking of rhizomorphomes does not have precedence over the marking of metamorphomes, nor vice versa. Instead, existing divisions between rhizomorphomes constrain the progression of metamorphome markers, and existing divisions between metamorphomes constrain the progression of rhizomorphome markers: rhizomorphomes and metamorphomes are orthogonal to one another, rather than participating in a hierarchical structure where one is superordinate to the other.

This finding complements Round's (2015) discussion of morphological complexity and different types of morphome. Round proposes a typology recognising three types of morphome: rhizomorphomes, which are groups of lexical items, defined by 'similarity of paradigms', metamorphomes, which are groups of paradigm cells, defined by 'incidence of meromorphomes', and meromorphomes, which pertain to how inflectional formatives are combined within a wordform. Round (2015: 49) claims that morphomic categories are divisible into subcategories, and thus have hierarchical structure, but this claim is only made in relation to individual types of morphome. Inflectional classes, for instance, can be grouped into subclasses, and formalised within inheritance hierarchies, as in the Network Morphology approach set out by Corbett \& Fraser (1993) and Brown \& Hippisley (2012); while within a metamorphome, recurrent

\footnotetext{
$33 / \mathrm{u} /$ is represented $\langle\mathrm{o}\rangle$, <ó $>$ in standard Occitan orthography, as used here.

34 This development might be viewed as an instance of analogical levelling in which a given form is generalised to all instances of a given meaning, creating a biunique relationship between the form and the meaning. The 'meaning' in this case would be a purely morphological one: the metamorphome to which the cell belongs.
} 
Preprint of: Esher, Louise. 2016. Morphomic distribution of augments in varieties of Occitan. Revue Romane 51(2). 271-306.

distributions of allomorphy may occur (O'Neill 2011). With regard to relationships between different types of morphome, by contrast, Round makes no explicit claim, and his typology should not be interpreted as implicitly making one. Although paradigm cells enter into a part-whole relationship with lexemes, it does not automatically follow from this observation that the categories relating to cells (i.e. metamorphomes) should themselves be internal to, or subordinate to, the categories relating to lexemes (i.e. rhizomorphomes). Indeed, a non-hierarchical relationship may be seen as a reflection of the fundamentally arbitrary nature of morphomes: the hierarchies identified for syntax and semantics are based on expressive functional content, a property which cannot be invoked to compare rhizomorphomes with metamorphomes.

In conclusion, the Occitan data discussed here support a non-hierarchical relationship between the two types of morphome, since marking of rhizomorphomes does not take precedence over marking of metamorphomes, and metamorphomic patterns such as PYTA and Fuèc can occur with distinctive exponents in any or all conjugational classes.

\section{Concluding remarks}

This article describes the range of augment-distributions found in varieties of Occitan, complementing earlier comparative studies of other Romance varieties. While the paradigmatic distributions encountered in Occitan can differ from those found elsewhere, the underlying principle at work is consistent: arbitrary allomorphy is distributed according to established morphological templates. This tendency can be explained as an adaptive strategy to increase the predictability, and hence the learnability, of inflectional paradigms.

Many Occitan varieties present multiple augments within a paradigm, only some of which can be traced to the Latin formatives -ĒSC- and -ĪSC-. This study identifies the source of the other augments as velar formatives arising in the third conjugation through regular sound change. Subsequently interpreted as markers of the metamorphome PYTA, these formatives are spread by analogy into other conjugations; in the second conjugation, they co-occur with the distinctive theme vowel /i/, producing a formative which is not dissimilar to the reflexes of -İSC-.

The general tendency observed is for augments to spread more widely through individual paradigms and through the lexicon. Extension within the inflectional paradigm of an individual lexeme, from a subset of paradigm cells to additional paradigm cells, is correlated with the neutralisation of conjugational class distinctions, though no functional motivation for maintaining class distinctions was found in this study. Both extension within a paradigm and extension through the lexicon illustrate the interaction of two types of morphomic pattern - metamorphomes and rhizomorphomes - as augments and theme vowels in Occitan act as exponents of both types. The spread of inflectional class markers through a paradigm progresses according to metamorphomic templates, while the spread of metamorphome signantia through the lexicon progresses according to rhizomorphomic templates, the two types of template being orthogonal to one another. 
Preprint of: Esher, Louise. 2016. Morphomic distribution of augments in varieties of Occitan. Revue Romane 51(2). 271-306.

\section{References}

ALLOc = Ravier, Xavier (1978-1993) : Atlas linguistique et éthnographique du Languedoc occidental. Paris, CNRS.

ALLOr = Boisgontier, Jacques (1981-1986): Atlas linguistique et éthnographique du Languedoc oriental. Paris, CNRS.

Ackerman, Farrell, James P. Blevins \& Robert Malouf (2009) : Parts and wholes: Implicative patterns in inflectional paradigms, in : Blevins, James P. \& Juliette Blevins (eds.): Analogy in grammar. Oxford, OUP, pp. 54-82.

Ackerman, Farrell \& Robert Malouf (2013) : Morphological organization: The low conditional entropy conjecture. Language, 89, pp. 429-464.

Ademá Mora, Casimiro (1966) : Estudio sobre el dialecto aranés. Barcelona, Editorial Occitania.

Albright, Adam (2009) : Modeling analogy as probabilistic grammar, in : Blevins, James P. \& Juliette Blevins (eds.): Analogy in grammar. Oxford, OUP, pp. 185-213.

Alibèrt, Loís (1976) : Gramatica occitana segon los parlars lengadocians. Segonda edicion. Montpelhièr, CEO.

Anglade, Joseph (1919) : Las Leys d'Amors. Manuscrit de l'Académie des Jeux Floraux. Toulouse, Privat. Aronoff, Mark (1994) : Morphology by itself. Stems and inflectional classes. Cambridge, Mass., MIT Press.

Bach, Xavier \& Louise Esher (2015) : Morphological evidence for the paradigmatic status of infinitives in French and Occitan, in : Dag T. T. Haug (ed.): Historical Linguistics 2013. Amsterdam, Benjamins, pp. 135-154.

Bec, Pierre (1968) : Les interférences linguistiques entre gascon et languedocien dans les parlers du Comminges et du Couserans. Paris, PUF.

Bianco, Giovanna, Franco Bronzati, Jean-Michel Effantin, Philippe Martel \& Rosella Pellerino [Comission internacionala per la normalizacion linguística de l'occitan alpin] (2008) : Nòrmas ortograficas, chausias morfolòicas e vocabulari de l'occitan alpin oriental. Espaci Occitan Regione Piemonte, Coni.

Blinkenberg, Andreas (1939) : Le Patois d'Entraunes. Copenhagen, Munksgaard.

Blinkenberg, Andreas (1948) : Le Patois de Beuil. Copenhagen, Munksgaard.

Brown, Dunstan \& Andrew Hippisley (2012) : Network Morphology. A defaults-based theory of word structure. Cambridge, CUP.

Buridant, Claude (2000) : Grammaire nouvelle de l'ancien français. Paris, SEDES.

Bybee, Joan \& Mary Brewer (1980) : Explanation in morphophonemics: Changes in Provençal and Spanish preterite forms. Lingua, 52, pp. 201-242.

Camproux, Charles (1962) : Essai de géographie linguistique du Gévaudan. Montpellier, PUF.

Carrera, Aitor (2007) : Gramatica aranesa. Lhèida, Pagès.

Carstairs-McCarthy, Andrew (1994) : Inflection classes, gender, and the principle of contrast. Language, 70, pp. 737-88.

Casagrande, Sylvain (2011) : L'unité et la diversité des systèmes verbaux en langue d'oc et dans les aires limitrophes. Essai de reconstruction. Doctoral thesis, Université de Nice. 
Preprint of: Esher, Louise. 2016. Morphomic distribution of augments in varieties of Occitan. Revue Romane 51(2). 271-306.

Corbett, Greville G. \& Norman M. Fraser (1993) : Network Morphology: A DATR account of Russian nominal inflection. Journal of Linguistics, 29(1), pp. 113-142.

Coromines, Joan (1991) : El parlar de la Vall d'Aran. Gramàtica, diccionari i estudis lexicals sobre el gascó. Barcelona, Curial Edicions Catalanes.

Dalbera, Jean-Philippe (1994) : Les parlers des Alpes-Maritimes : étude comparative, essai de reconstruction. London, AIEO.

Da Tos, Martina (2013) : The Italian FINIRE-type verbs: a case of morphomic attraction, in : Cruschina, Silvio, Martin Maiden \& John Charles Smith (eds.): The boundaries of pure morphology. Oxford, OUP, pp. 45-67.

Enger, Hans-Olav (2012) : Morphological theory and grammaticalisation: the role of meaning and local generalisations. Language Sciences, 36, pp. 18-31.

Enger, Hans-Olav (2014) : Reinforcement in inflection classes: Two cues may be better than one. Word Structure 7(2), pp. 153-181.

Esher, Louise (2012a) : Future, conditional and autonomous morphology in Occitan. D. Phil thesis, University of Oxford.

Esher, Louise (2012b) : The morphological evolution of infinitive, future and conditional forms in Occitan, in : Kemenade, Ans van \& Nynke de Haas (eds.): Historical Linguistics 2009: selected papers from the 19th International Conference on Historical Linguistics. Amsterdam, Benjamins, pp. 315-332.

Esher, Louise (2013) : Future and conditional in Occitan: a non-canonical morphome, in : Cruschina, Silvio, Martin Maiden \& John Charles Smith (eds.): The Boundaries of Pure Morphology: Diachronic and Synchronic Perspectives. Oxford, OUP, pp. 95-115.

Fabra, Pompeu (1966) : Gramàtica catalana. Barcelona, Teide.

Grosclaude, Michel \& Gilabèrt Nariòo (1998) : Répertoire des conjugaisons occitanes de Gascogne. Ortès, Per Noste/La Civada.

Jourdan, Rino (2009) : Lou Vërnantin/Lo Vernantin. La Ròcha, Chambra d'Oc.

Kirby, Simon, Tom Griffiths \& Kenny Smith (2014) : Iterated learning and the evolution of language'. Current Opinion in Neurobiology, 28, pp. 108-114.

Laurent, Jean-Pierre (2001) : Le Dialecte de la vallée de Massat. Montséron, J-P Laurent.

Laurent, Jean-Pierre (2002) : Le Dialecte gascon d'Aulus. Montséron, J-P Laurent.

Lieutard, Hervé (2004) : Phonologie et morphologie du parler occitan de Graulhet (Tarn). Structure, contenu et rôle de la syllable. Montpellier, CEO/Université Paul Valéry.

Maiden, Martin (1995) : A Linguistic History of Italian. London, Longman.

Maiden, Martin (1996) : The Romance gerund and System-Dependent Naturalness in morphology. Transactions of the Philological Society, 94, pp. 167-201.

Maiden, Martin (2001) : A strange affinity: perfecto y tiempos afines. Bulletin of Hispanic Studies, 58, pp. 441-464.

Maiden, Martin (2004) : Verb augments and meaninglessness in Romance morphology. Studi di grammatica italiana, 22, pp. 1-61.

Maiden, Martin (2005) : Morphological autonomy and diachrony. Yearbook of Morphology, 2004, pp. 137175.

Maiden, Martin (2009a) : From pure phonology to pure morphology. The reshaping of the Romance verb. Recherches Linguistiques de Vincennes, 38, pp. 45-82. 
Preprint of: Esher, Louise. 2016. Morphomic distribution of augments in varieties of Occitan. Revue Romane 51(2). 271-306.

Maiden, Martin (2009b) : Where does heteroclisis come from? Evidence from Romanian dialects. Morphology, 19, pp. 59-86.

Maiden, Martin (2011a) : Morphological persistence, in : Maiden, Martin, John Charles Smith \& Adam Ledgeway (eds.): The Cambridge History of the Romance Languages. Cambridge, CUP, pp. 155215.

Maiden, Martin (2011b) : Morphophonological innovation, in : Maiden, Martin, John Charles Smith \& Adam Ledgeway (eds.): The Cambridge History of the Romance Languages. Cambridge, CUP, pp. 216-267.

Maiden, Martin (2012) : A paradox? The morphological history of the Romance present subjunctive. in : Gaglia, Sascha \& Marc-Olivier Hinzelin (eds.): Inflection and word formation in Romance languages. Amsterdam, Benjamins, pp. 27-54.

Maiden, Martin (2013) : The Latin 'third stem' and its Romance descendants. Diachronica, 30, pp. 492530.

Maiden, Martin (forthcoming 2016) : Some Lessons from History. Morphomes in Diachrony', in : Luís, Ana \& Ricardo Bermúdez-Otero (eds.): The morphome debate: diagnosing and analysing morphomic patterns. Oxford, OUP.

Martin, Guy \& Bernard Moulin (2007) : Grammaire provençale et cartes linguistiques. Deuxième édition revue et corrigée. Aix-en-Provence: Comitat Sestian d'Estudis Occitans.

Maschi, Roberta \& Laura Vanelli (2010) : Morfologia verbale, in : Salvi, Giampaolo \& Lorenzo Renzi (eds.): Grammatica dell'italiano antico. Vol.II. Bologna, il Mulino, pp. 1431-1491.

Matthews, Peter (2014) : The concise Oxford dictionary of linguistics. Oxford, OUP. DOI: 10.1093/acref/9780199675128.001.0001 (accessed 7 March 2015).

Meul, Claire (2010) : The intra-paradigmatic distribution of the infix $-I / E S C$ - from Latin to Modern Romance: morphomic patterning and beyond. Morphology, 20, pp. 1-40.

Meul, Claire (2013) : The Romance reflexes of the Latin infixes -I/ESC- and -IDI-: restructuring and remodeling processes. Hamburg, Buske.

Moll, Francesc de B. (1952) : Gramática histórica catalana. Madrid, Gredos.

Moulin, Bernard (2006) : Grammaire occitane : le parler bas-vivarois de la région d'Aubenas. Aubenas, IEO.

Nevins, Andrew, Cilene Rodrigues \& Kevin Tang (2015) : The rise and fall of the L-shaped morphome: diachronic and experimental studies. Probus, 27(1), pp. 101-155.

O'Neill, Paul (2011) : The notion of the morphome, in : Maiden, Martin, John Charles Smith, Marc-Olivier Hinzelin \& Maria Goldbach (eds.): Morphological Autonomy: Perspectives from Romance inflectional morphology. Oxford, OUP, pp. 70-94.

Pope, Mildred K. (1934) : From Latin to Modern French. Manchester, University of Manchester.

Ravier, Xavier (1970) : Flexion dite inchoative en languedocien ariégeois et fait dialectal. Via Domitia, 16, pp. 17-29.

Rodríguez Castellano, Lorenzo (1952) : La varietat dialectal del Alto Aller. Oviedo, Instituto de Estudios Asturianos.

Romieu, Maurice \& André Bianchi (2005) : Gramatica de l'occitan gascon contemporanèu. Bordeaux, Presses Universitaires de Bordeaux. 
Preprint of: Esher, Louise. 2016. Morphomic distribution of augments in varieties of Occitan. Revue Romane 51(2). 271-306.

Ronjat, Jules (1937) : Grammaire istorique des parlers provençaux modernes, vol. III. Montpellier, Société des Langues Romanes.

Round, Erich (2015) : Rhizomorphomes, meromorphomes and metamorphomes, in : Baerman, Matthew, Dunstan Brown \& Greville G. Corbett (eds.): Understanding and measuring morphological complexity. Oxford, OUP, pp. 29-52.

Roux, Jean \& Jean-Louis Lévêque (2011) : Précis de conjugaison occitane. Dialecte limousin. Périgueux, Novelum/IEO.

Sanchis Guarner, Manuel (1950) : Gramàtica valenciana. València, Torre.

Skårup, Povl (1997) : Morphologie élémentaire de l'ancien occitan. Copenhagen, Museum Tusculanum Press.

Stump, Gregory \& Raphael A. Finkel (2013) : Morphological Typology. From Word to Paradigm. Cambridge, CUP.

Toscano, Reinat (1996) : Conjugar en niçard. Nice, Auba Novèla.

Toscano, Reinat (1998) : Gramàtica niçarda. Toulouse, Princi Néguer.

Wheeler, Max (1988) : Occitan, in : Harris, Martin \& Nigel Vincent (eds.): The Romance Languages. London, Routledge, pp. 246-277.

Wheeler, Max (2011): The Evolution of a Morphome in Catalan Verb Inflection, in : Maiden, Martin, John Charles Smith, Marc-Olivier Hinzelin \& Maria Goldbach (eds.): Morphological Autonomy: Perspectives from Romance inflectional morphology. Oxford, OUP, pp. 183-209.

Winkelmann, Otto (1989) : Untersuchungen zur Sprachvariation des Gaskognischen im Val d'Aran (Zentralpyrenäen). Tübingen, Niemeyer. 
Preprint of: Esher, Louise. 2016. Morphomic distribution of augments in varieties of Occitan. Revue Romane 51(2). 271-306.

\section{Annexe}

Map of ALLOc survey points referred to in the text

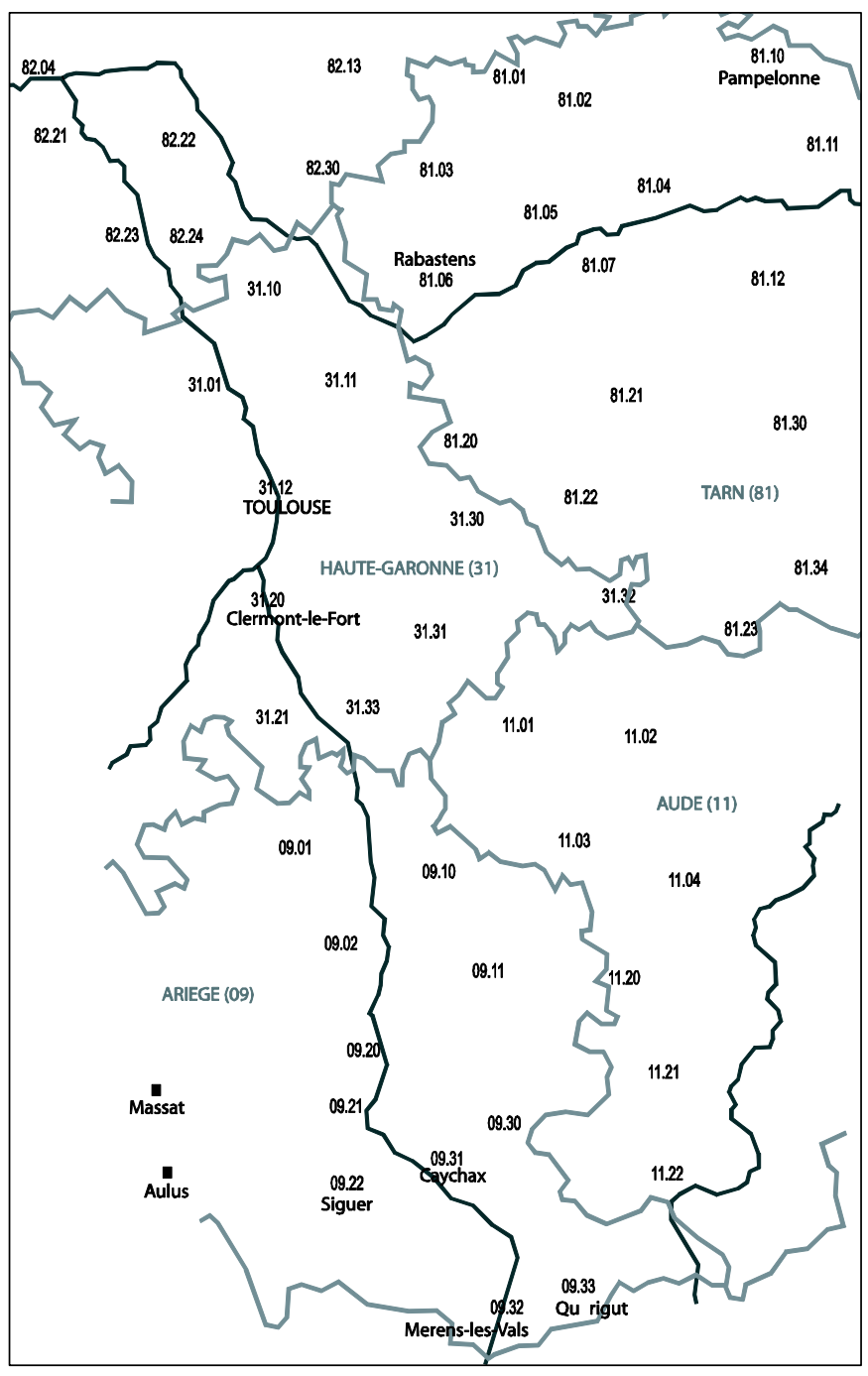

